\title{
HOW HISTORY HAS SHAPED THE HONG KONG REVENUE REGIME
}

\author{
BY \\ RICHARD CULLEN \\ Email: richard.cullen@gmail.com
}

AND

ANTONIETTA WONG

Email: antonietta.wong@idx.com.au 


\title{
HOW HISTORY HAS SHAPED THE HONG KONG REVENUE REGIME
}

\begin{abstract}
Hong Kong has had a remarkable history. Prior to the British acquiring sovereignty over Hong Kong Island in the early 1840s (essentially at the point of a gun) it was a sparsely populated, far flung outpost of the Chinese Empire devoted mainly to fishing and traditional farming. Under British rule, it grew, over time, to become one of the most successful City-States in the modern world. In 1997, this high-rise remnant of the British Imperial adventure once more reverted to the sovereignty of China: now the People's Republic of China (PRC). The PRC is not only the world's largest One Party State - it is also its most successful.

The development of Hong Kong's British influenced Revenue Regime is also remarkable. The early configuration of that system was a direct product of what is sometimes referred to as the first era of globalization, which was a profoundly energized by European colonization and empire building. The aggressive, ultimately violent, Japanese response to that European example drove further changes in the Hong Kong Tax System. Yet, the system which emerged in Hong Kong after World War II looked a lot like a recreation from a $19^{\text {th }}$ century Tax Museum. This, more by accident than design, proved especially well suited to fostering Hong Kong's dramatically successful integration into the post-war, world trading system as the modern era of globalization began. Today, Hong Kong's Tax System is adapting further to newer regional and global trading relationships.

This paper provides an overview of the historical development of Hong Kong's Revenue Regime and the way it which has been shaped continuously, by its own most particular history.
\end{abstract}




\section{HOW HISTORY HAS SHAPED \\ THE HONG KONG REVENUE REGIME}

TABLE OF CONTENTS

\subsection{INTRODUCTION}

2.0 POLITICAL STRUCTURE EVOLUTION

2.1 COLONIAL POWER WITHIN THE BRITISH EMPIRE

2.2 THE CROWN COLONY OF HONG KONG

2.3 GOVERNANCE STRUCTURE OF THE HKSAR

3.0 REVENUE REGIME EVOLUTION

3.1 FINANCING THE COLONIES

3.2 REVENUE REGIME DEVELOPMENT IN HONG KONG

3.2.1 The Initial Phase

3.2.2 Income Tax Commences

3.2.3 Overview of the Current Revenue Regime

3.2.4 The Fiscal Firewall

3.2.5 Double Tax Treaties

4.0 GLOBALIZATION AND THE REVENUE REGIME

\subsection{CONCLUSION}




\section{HOW HISTORY HAS SHAPED THE HONG KONG REVENUE REGIME}

BY

RICHARD CULLEN AND ANTONIETTA WONG ${ }^{1}$

\subsection{INTRODUCTION}

This paper is, essentially, a case study of the long-term impact of globalization on the development of the Revenue Regime in Hong Kong. ${ }^{2}$ Revenue Regime is the broad term which we use to denote the full array government money raising mechanisms (apart from fines and debt) deployed, historically and today, in Hong

Kong. As we explain below, Hong Kong has, from the start of the period of its modern history, relied, importantly, on mechanisms other than conventional

1 Richard Cullen: LLB(Hons) University of Melbourne, Australia, PhD Osgoode Hall Law School, Canada, Visiting Professor, Faculty of Law (FLW), The University of Hong Kong (HKU). CoDirector, Taxation Law Research Programme, FLW, HKU, Research Associate, Civic Exchange, Hong Kong and Research Fellow, Taxation Law and Policy Research Institute, Monash University, Australia. Antonietta Wong: PhD Monash University, Australia, Research Fellow, Taxation Law and Policy Research Institute, Monash University, Australia. This paper is a republished version of a paper previously published electronically by Civic Exchange in Hong Kong (see: http://www.civic-exchange.org/eng/upload/files/200812 hkTaxRegime.pdf.) Internet-based citations were all current at the time of writing. Richard Cullen has retained hard copies of cited items. An earlier version of this paper was presented at a Symposium held on February 29, 2008 at Queen's University, Kingston, Ontario in Canada, in honour of the late Professor Alex Easson. We are grateful to the organizers of the Symposium for their agreement to re-publish this work.

2 The leading Canadian tax scholar, Alex Easson, wrote extensively, prior to his death in January, 2007, about the impact of international factors on the shaping of municipal Tax Systems - and the way that different Tax Systems interact with one another. He also considered, in considerable depth, the importance of the concept of source and the role it played in the day to day operation of many Tax Systems. See, for example: Easson, Alex, Common Law Approaches to the Determination of the Source of Income (2006) 60 Bulletin for International Taxation, 495; Easson, Alex, Harmful Tax Competition: An Evaluation of the OECD Initiative (2004) 34 Tax Notes International, 1037; and Easson Alex, Do We Still Need TaxTtreaties? (2000) 54 Bulletin for International Fiscal Documentation, 619. His writing has stimulated both of us to re-think how the Revenue Regime has developed in Hong Kong since 1841 and what have been the key international political, economic, social - and tax - influences on that process. 
taxation to raise public revenues. The two most notable non-tax sources of public revenue, historically, have been government dealings related to opium and land. Opium trade revenues ceased to be a key source of government income in Hong Kong by the 1920s. Direct and indirect land-transaction revenues remain a notable feature of the current Hong Kong Revenue Regime. We use the term Tax System, below, to refer to that part of the broad public revenue system which relies on recognizable forms of direct and indirect taxation. ${ }^{3}$

When we think, today, about globalization, we tend to consider it as a post World War Two (WW II) phenomenon which has gathered truly significant pace as the communications-technology revolution has unfolded over the last two decades. ${ }^{4}$ This modern version of globalization has deep foundations, however, within the type of integrated global economy which was developed for well over 100 years prior to World War One (WWI) - during the colonial era. Primarily, the colonial era involved European based colonizers and non-European colonized jurisdictions. In terms of scope and political and economic durability, the British Empire was the pre-eminent product of this period of world development (notwithstanding the loss of the American Colonies in the American

The principal (since WW II) tax imposing law in Hong Kong is the Inland Revenue Ordinance (1947). The term Ordinance signifies (amongst other things) in Anglo Common Law, a form of delegated legislation, such as the laws passed by an inferior, colonial legislature, see: Walker, David M., The Oxford Companion to Law (Clarendon Press, Oxford, 1980) 906. All HKSAR laws continue to be called Ordinances - apart from the Basic Law (see below).

"The term "globalization" describes the increased mobility of goods, services, labour, technology and capital throughout the world. Although globalization is not a new development, its pace has increased with the advent of new technologies, especially in the area of telecommunications." See, Globalization Definition at: http://www.canadianeconomy.gc.ca/english/economy/globalization.html 
Revolutionary War). ${ }^{5}$ Today, very little of the offshore (former) British Empire remains within the control of the UK. The small (6.5 square kilometres) Overseas Territory of Gibraltar is one of the few remaining exceptions. ${ }^{6}$

Prior to July 1997, the Overseas Territory of Hong Kong was also such an exception. On July 1 of that year, sovereignty over Hong Kong reverted to the People's Republic of China (PRC) and the former British Territory became the Hong Kong Special Administrative Region (HKSAR) of the PRC. ${ }^{7}$ The HKSAR acquired, at this time, a new Constitution, the Basic Law of the Hong Kong Special Administrative Region of the People's Republic of China (Basic Law) ${ }^{8}$.

$5 \quad$ See: British Empire, Encyclopedia Britannica, at: http://www.britannica.com/eb/article9016519/British-Empire; and British Empire, at: http://en.wikipedia.org/wiki/British_Empire.

6 See, Gibraltar, at: https://www.cia.gov/library/publications/the-world-factbook/geos/gi.html.

$7 \quad$ Hong Kong consists of Hong Kong Island, the Kowloon Peninsula situated on the Mainland opposite Hong Kong Island, the New Territories comprising the area north of Kowloon up to the Shenzhen River and 235 islands. Hong Kong Island was ceded in perpetuity to Britain by China in 1842 at the end of the First Opium War (1839-1842) pursuant to the Treaty of Nanking (Nanjing). The Kowloon Peninsula was ceded in perpetuity in 1860 at the end of the Second Opium War (1856-1860) under the Convention of Peking (Beijing). The New Territories and the islands were leased for 99 years from July 1, 1898 under the Convention Respecting the Extension of Hong Kong Territory. The HKSAR was established in accordance with the Joint Declaration of the Government of the United Kingdom of Great Britain and Northern Ireland and the Government of the People's Republic of China on the Question of Hong Kong (Joint Declaration) signed on December 19, 1984. The PRC declared in the Joint Declaration that it had decided to resume the exercise of sovereignty over Hong Kong (the leased territories, together with Hong Kong Island and Kowloon) with effect from July 1, 1997. The UK declared that it would restore Hong Kong to the PRC with effect from July 1, 1997. The Joint Declaration entered came into force on May 27. 1985 when the two governments exchanged instruments of ratification. It was registered as a treaty at the United Nations by the Chinese and British governments on June 12, 1985 , which creates international rights and obligations for both parties to it.

$8 \quad$ The Basic Law was adopted by the National People's Congress of the PRC on April 4, 1990 and came into force on July 1, 1997. The Court of Final Appeal, the pinnacle of the judicial process (which is entirely separate, under the Basic Law) found, in 1999, that the Basic Law enjoyed constitutional status within the HKSAR (Ng Kar Ling \& Others v. Director of Immigration [1991] 1 Hong Kong Law Reports \& Digest, 315). Much more recently, the President of the PRC, Hu Jintao, endorsed the "supreme status of the Basic Law" in Hong Kong and also noted that, apart from the HKSAR, all levels of government and all people on the Mainland [PRC] must observe the Basic Law (see: Hu, Jintao, Passing the test, South China Morning Post, July 2, 2007, A14 
In the period since the end of WW II, in 1945, two City-States ${ }^{9}$ have thrived in East Asia; Singapore and Hong Kong. Both owe their modern beginnings to their choosing, by the British, as key ports servicing the trading and military needs of the $19^{\text {th }}$ century, British Empire. The British were attracted by the safe anchorages offered by the deep waters surrounding both Singapore and Hong Kong. Moreover, they possessed the military might to assert their interest.

Prior to the arrival of the British in 1841, Hong Kong was home to a series of scattered Chinese fishing and farming communities. For over 150 years, the British maintained Hong Kong as an enclave, plainly separated from Mainland China in many ways. We have recently passed the $10^{\text {th }}$ anniversary of Beijing's resumption of dominion over what is now the HKSAR. Notwithstanding Hong Kong's return to the "Motherland", the bustling city at the mouth of the Pearl River remains a very separate enclave within China. Hong Kong, today, operates as a City-State within the most populous nation on Earth and within the largest One Party State (OPS) - run by the Chinese Communist Party (CCP) - the world has

(English text of speech made by President Hu Jintao at the inauguration of the new HKSAR Government on July 1, 2007)). These comments by the President could be argued to recognize the elevation of the Basic Law to a status above Mainland PRC laws in certain matters directly related to Hong Kong.

9 City-States are typically defined as "an independent political unit consisting of a city and surrounding countryside. They reached their peak in ancient Greece, although a number, like Florence, Venice and Genoa endured in Italy until the middle of the $19^{\text {th }}$ century. Bremen and Hamburg also retained this status until they were absorbed into the modern German State. See, http://www.answers.com/topic/city-state. (See, too: Glotz, G, The Greek City and Its Institutions (Knopf, New York, 1951 (reprinted 1969)); and Ehrenberg, V., The Greek State (2 ${ }^{\text {nd }}$ Ed.) (Methuen, London, 1969 (reprinted 1972)). 
ever seen. ${ }^{10}$ As we shall see, the HKSAR is today even more fiscally separated from the PRC Mainland ${ }^{11}$ than Hong Kong was from the UK.

Hong Kong has had to grapple with all manner of challenges over the last 100 plus years, relying, for the greater part, primarily on its own local resources. By one count, these are minimal. The most striking natural resource is the large, deepwater harbour (which so attracted the British in the 1840s). Next, there is the geographical location. Nowadays, around $50 \%$ of the world's population resides within 4 hours flying time. Few other places hold a better claim to being at a "cross-roads" location. Hong Kong's most significant asset, though, has been its largely Chinese, local population.

Our aim in this paper is to explain how the Revenue Regime in Hong Kong has developed over the course of its remarkable modern history. Throughout the period of this history, this regime has been notably shaped by the power of globalization. This continues to be the case today.

10 The Chinese OPS is still primarily organized, politically, according to principles laid down by Lenin. Thus, only the CCP is permitted to exercise any meaningful political power. Economically, the PRC has abandoned, to a very large extent, Marxist principles of economic organization and regulation. For a review of this phenomenon, see, Roberts, J.A.G., A History of China ( $2^{\text {nd }}$ ed.) (Palgrave-MacMillan, Basingstoke, 2006) Chapter 7.

11 We use the terms, "PRC Mainland" and "Mainland" to indicate the PRC, excluding the HKSAR the MacauSAR and Taiwan. These four entities are sometimes collectively referred to as "Greater China". The HKSAR and the MacuaSAR are both recognized as also being component jurisdictions within the PRC enjoying a special level of autonomy within the PRC Unitary State. Taiwan, has remained entirely separated from the PRC in an operational sense since the end of the Chinese Civil war in 1949. Few nations recognize Taiwan as a separate country at International Law, however. Beijing regards Taiwan as a "renegade Province" of the PRC. See, for a short historical overview of the history of the Chinese Unitary State and the relationship of the components of Greater China to that Unitary State: Cullen, Richard, Political Reform in Hong Kong -Within Greater China (2007) Politika Annual Journal, 59. 
One can identify three broad periods of globalized influence on the development of the Hong Kong Tax System. These can be expressed as: (A) the Imperial Globalization era; (B) the Cold War Globalization era; and (C) the Modern Globalization era. Category A covers the primary colonial era. Category B covers the first forty-plus years of the post WW II era when world trade began to be notably re-integrated. This "normal" world trade system encompassed the Western developed nations and much of the developing world. However, alongside this system there existed the very significant, often culpably inefficient trade-world of the Communist-bloc countries (also known as the "Eastern Bloc"). This latter system was grumpily and awkwardly connected to the "normal" system when it suited or was necessary. But throughout this era, until 1989, the West (headquartered in Washington) and the East (headquartered in Moscow) maintained an intense militarized standoff which spawned recurrent proxy-war offshoots. $^{12}$ In November 1989, the Berlin Wall was opened (and later came down) signaling the end of the Cold War era. ${ }^{13}$ At about the same time, a new technology revolution began to gather serious pace. In particular, it transformed the cost, capacity and availability of computing capacity and, via the Internet, world-wide communications. ${ }^{14}$ This combination of the collapse of the Eastern

12 See, Cold War, Oxford Paperback Encyclopedia (Oxford University Press, Oxford, 2000).

13 See, Berlin, Oxford Paperback Encyclopedia (Oxford University Press, Oxford, 2000). In fact, President George Bush of the USA and President Mikhail Gorbachev of the former USSR, declared that the Cold War was officially over at a summit in Malta in December 1989, Cold War, ibid.

14 See, Communications, Oxford Paperback Encyclopedia (Oxford University Press, Oxford, 2000). 
Bloc economic system and the communications revolution were particularly energizing, as it turned out, for world trade and thus the Modern Globalization era commenced. ${ }^{15}$

Directly below, we explain the evolution of the governance structure of the HKSAR within the context of Hong Kong's political development as a component in the British Empire. In Part 3, we review the historical (colonial) development of Hong Kong's Revenue Regime prior to providing an overview of that regime as it applies, today, in the HKSAR. Parts 2 and 3 lay the foundations for the discussion, in some depth, in Part 4 of the long-term intersection between globalization and the shaping of the Tax System in Hong Kong. Part 5 is the Conclusion.

\subsection{POLITICAL STRUCTURE EVOLUTION}

\subsection{COLONIAL POWER WITHIN THE BRITISH EMPIRE}

Following the loss, by Britain, of the American Colonies by $1782,{ }^{16}$ the political system in the United Kingdom (UK) progressively underwent a series of fundamental changes. The then still politically active Monarchy was deeply discredited by defeat in America (in what became the United States of America (USA)). Parliament had notably asserted itself, at the expense of the Monarchy, following the "Glorious Revolution" in 1688. But in the $18^{\text {th }}$ century, the Monarch

$15 \quad$ See footnote 4.

16 Timeline of the American Revolutionary War, at: http://www.ushistory.org/march/timeline.htm. 
was still a key political actor, especially in foreign affairs. Parliament remained a comparatively weak institution in many respects. The Judiciary was, by then, well established as an institution enjoying significant independence. ${ }^{17}$

Over the decades following defeat in America (and especially after the death of George III in 1820) power moved markedly from the Monarchy to Parliament. More significantly, it moved to the Executive Government within Parliament. Westminster or Parliamentary Government thus emerged as the product of a remarkable, "measured revolution", as the new political model for the UK. The essence of this system mandates (as a matter of convention in the UK) that every member of the Government must be a serving member of the Parliament (House of Commons or House of Lords). Governments become so by establishing themselves as enjoying continuing majority support in the House of Commons (or the Lower House of Parliament in a Westminster-style, bicameral system). ${ }^{18}$

Despite these radical developments within the UK itself, this new political model was not immediately exported throughout the British Empire. The British retained what might be termed the "George III model" (a very powerful Executive, a

17 See: Parliament of Great Britain, in Walker, op. cit. note 3.

18 See: Parliament of England, Parliament of Great Britain and Parliament of the United Kingdom, ibid. Another term arising from this political-software-revolution was "Constitutional Monarchy". This emerged as the term which best described the new, greatly reduced figurehead status for the Monarch. See: Parliament of the United Kingdom, ibid; and Monarchy, in Crystal, David, (ed.) The Cambridge Paperback Encyclopedia $\left(3^{\text {rd }}\right.$. ed.) (Cambridge University Press, Cambridge, 1993). 
comparatively weak Legislature and a separate Judiciary) as its colonial governance template administered through what came to be known as the Colonial Office. The position of Secretary of State for the Colonies was first established in 1768 in response to restiveness in the American Colonies. By 1801, after the loss of those colonies a new position of Secretary of State for War and the Colonies was established. In 1854 a fully separate Colonial Office was established under the now Secretary of State for the Colonies. ${ }^{19}$

By the late $18^{\text {th }}$ century, a regular pattern for the administration of British territories overseas was established; a Governor appointed by the Crown was assisted by a nominated Executive and Legislative Council. Typically, a separate Judiciary was also established. This governance structure was commonly set down in a principal (Executive issued rather than legislatively enacted) separate document for each colony called the Letters Patent (equivalent to a Constitution). Each British colonial jurisdiction had a subordinate Legislature, as opposed to a sovereign Legislature. The authorities in such colonies normally were not competent to pass laws which had extra-territorial effect. (This meant, inter alia, that such colonies could not institute a system of taxation based on residence because the relevant Government would not possess the power to tax effectively beyond the geographic borders of its territory.) Describing the particular (and typical) case of Hong Kong, Edwards put it this way:

19 See, Secretary of State for the Colonies, at: http://en.wikipedia.org/wiki/Secretary of State for the Colonies. 
Authority emanates from the Queen in Council in Great Britain and, under certain Orders in Council, consolidated under what are called the Hong Kong Letters Patent 1917-1988, authority is delegated to a Governor appointed by the Crown and the Legislative and Executive Councils in Hong Kong Clause VII of the Letters Patent provides that "the Governor, by and with the advice and consent of the Legislative Council, may make laws for the peace, order and good government of the Colony". Such words, or words similar in effect, have been used in almost all of the Letters Patent constituting the governments of British colonies and there is a substantial body of case law relating to them. The Governor in Council is a subordinate legislative body and, for any law to be validly made under the Letters Patent, there must be a sufficient nexus with the Colony. The Hong Kong government cannot enact legislation which does not have a real connection with the Colony. The jurisdiction of the Governor in Council extends to the colonial territories but not beyond. Further, para 8 of cl XXVI of the Hong Kong Royal Instructions 1917-1988, which supplement the Letters Patent, provides that "the Governor shall not assent to any Bill of an extraordinary nature and importance whereby [the Crown's] prerogative or the rights and property of [the Queen's] subjects not residing in the Colony, or the trade and shipping of [the] United Kingdom and its dependencies, may be prejudiced". These provisions have great significance in the context of the government's power to levy taxation. ${ }^{20}$

\subsection{THE CROWN COLONY OF HONG KONG}

Hong Kong became a Crown Colony within the British Empire with a constitution provided in the Letters Patent ${ }^{21}$ (and Royal Instructions) issued through the Privy Council in London. ${ }^{22}$ As noted above, this was the customary method the British

Edwards, Peter S. A. The Hong Kong Tax Structure: Recent Tax Developments (1992) 4(3) CCH Journal of Asian Pacific Taxation, 17. Although, this explanation over-emphasizes the importance of constitutional provisions as explanatory factors in the shaping of the Hong Kong Tax System, it does provide a good summary of nature of those provisions. See below for a less doctrinal, explanation for the application and retention of the territorial principle in Hong Kong.

21 See, Letters Patent, at: http://en.wikipedia.org/wiki/Letters patent.

22 The history and important operational aspects of Hong Kong's constitutional documentation under British rule are explained well in Ghai, Yash, Hong Kong's New Constitutional Order ( $2^{\text {nd }}$ ed.) (Hong Kong University Press, Hong Kong, 1999) Chapter 1. See, also, Hong Kong Basic Law, at: http://en.wikipedia.org/wiki/Basic_Law of Hong_Kong. See, also, Wesley-Smith, Peter, Constitutional and Administrative Law in Hong Kong (Longman Asia, Hong Kong, 1994). 
used for providing constitutional underpinnings to colonies like Hong Kong. ${ }^{23}$ Such colonies remained subject to the operation of the direct application of UK law in certain circumstances and their own law making powers were limited, normally, to laws having effect within the specific colony. Other larger, usually "white" dependencies within the British Empire, like the Australian Colonies, were provided with Westminster enacted constitutions and full Parliamentary systems of elected government - but their legislative powers remained restricted. ${ }^{24}$ The Letters Patent for Hong Kong, which were subject to a number of amendments, remained Hong Kong's primary constitutional document until the change of sovereignty in 1997.

Notwithstanding the addition of a fair amount of modern political embroidery (especially post WW II) the British retained the essence of this $18^{\text {th }}$ century system of governance in Hong Kong right through until the handover, in $1997 .{ }^{25}$ The task of governing British Hong Kong remained in the hands of a London appointed Governor working with a Civil Service notable for its very high level of political engagement. ${ }^{26}$ The fusion of politics and administration in the colonial

23 See, Letters Patent, at: http://85.1911encyclopedia.org/L/LE/LETTERS_PATENT.htm. See, also, http://www.parliament.uk/commons/lib/research/notes/snpc-3708.pdf.

24 For a typical example, see, Victoria (Australia) at: http://en.wikipedia.org/wiki/Victoria_\%28Australia\%29.

25 This same system has been used to form the primary HKSAR governance institutions which are embodied in the Basic Law.

26 An alternative meaning given for the term "bureaucracy" in the Chambers $21^{\text {st }}$ Century Dictionary (Chamber, Edinburgh, 1996) is "a country governed by officials". Hong Kong was, and still largely is, a bureaucracy in this sense. For further discussion of the structure and operation of Hong Kong' system of government see, Loh, Christine and Cullen, Richard, Political Reform in Hong Kong (2005) 14, Journal of Contemporary China, 147. 
model of government downplayed the importance of politics and political participation in policy-making. At the same time, the top layer of the Civil Service was in fact politicized as it also effectively played a political role.

The governance system that ultimately evolved in Hong Kong under British rule was something of a hybrid - part Presidential, part Parliamentary and embedded in a colonial tradition. Like the US, Hong Kong placed a great deal of power outside the legislature. In British Hong Kong, power rested in the hands of the Governor. That said the dominant influence has been the UK Parliamentary tradition. This explains why Hong Kong's Legislative Council (LegCo) has been able, over time, to build a de facto capacity to hold government to account in a partly-Parliamentary manner.

Despite the lack of democracy, Hong Kong was allowed, post WW II, to develop, under British rule, into the freest society in East Asia. The press and the media generally were able to flourish ${ }^{27}$ and the Rule of Law, implemented primarily through an independent Judiciary, put down deep roots. ${ }^{28}$

\subsection{GOVERNANCE STRUCTURE OF THE HKSAR}

$27 \quad$ Bonnin, Michel, The Press in Hong Kong - Flourishing but Under Threat (1995) 1 (September) China Perpectives, 48.

28 See, Ghai, Yash, Praise is not enough, South China Morning Post, March 22, 1998. See, also: Jones, Carol, Politics Postponed in (Jayasuriya (ed.)) Law, Capitalism and Power in Asia (Routledge, London, 1999). 
Currently, the HKSAR has what might best be described as a US-style, Presidential system of government (separated Executive and Legislature), heavily decorated with time-honoured colonial characteristics. This is the system inherited from the British. What Hong Kong does not have, despite more than 150 years of British rule, is a UK-style, Parliamentary system of government (Executive fully integrated with and answerable to the Legislature). Under the Basic Law, Hong Kong's post-1997 mini-Constitution, the HKSAR leader, the Chief Executive (CE), is still selected/elected by an 800 member Election Committee rather than by universal suffrage. None of the members of this Government are elected; they are all appointed (as is the Chief Executive) by Beijing. The HKSAR Legislature - LegCo - comprises a single house with 60 members. Half of LegCo is, today, elected using a system of universal suffrage. All adult permanent residents of the HKSAR are eligible to vote for these 30 LegCo members, who are chosen using a multi-seat, proportional representation electoral system. The remaining 30 LegCo members are elected by Functional Constituencies (FCs), another British inheritance. Several FC members stand unopposed in each LegCo election, due mainly to the extremely narrow franchise (below 500 voters) applying in certain FC seats. For all FCs, the franchise is very small compared to the franchise applying to directly elected LegCo seats. ${ }^{29}$

29 For a recent detailed overview of the operation of Hong Kong's current political system since 1997, see: for example, Lai, Carine and Loh, Christine, From Nowhere to Nowhere (Civic Exchange, Hong Kong, 2007). For a thorough review of the operation of the Functional Constituency system see: Loh, Christine and Civic Exchange (eds) Functional Constituencies (Hong Kong University Press, 2006). See, also, Cullen, Richard, Hong Kong: The Making of a Modern City-State (2006) 13 Murdoch E-Law Journal, 24, at: https://elaw.murdoch.edu.au/issues/2006/1/eLaw_Cullen_13_2006_03.pdf. 
The Basic Law sets out the way in which the HKSAR is to be administered for 50 years beyond 1997. It promised that the socialist system and policies in the PRC will not apply to the HKSAR under the doctrine of "One Country Two Systems" ${ }^{30}$ This doctrine provides that, although Hong Kong will become part of the PRC (One Country), it will retain a high degree of autonomy so as to maintain its current political economy (Two Systems). ${ }^{31}$ In other words, while the PRC will continue to practise "socialism with Chinese characteristics", Hong Kong is to continue the practice of "capitalism with Chinese characteristics". ${ }^{32}$

Matters related to foreign affairs ${ }^{33}$ and defence ${ }^{34}$ fall within the ambit of the Central People's Government in the PRC but Hong Kong has full management responsibility over many other matters. For example, the HKSAR shall:

- $\quad$ maintain its status as an international financial centre; ${ }^{35}$

- $\quad$ maintain its status of a free port; ${ }^{36}$

- $\quad$ issue passports; ${ }^{37}$

- $\quad$ maintain trial by jury; ${ }^{38}$

\footnotetext{
30 Article 5, Basic Law.

31 Cullen, Richard, Stability and Prosperity in Hong Kong: A Palette of Influences in (Taylor (ed.)) Asian Laws Through Australian Eyes (1997) 186.

$32 \quad$ Ibid.

33 Article 13, Basic Law

34 Article 14, Basic Law

35 Article 109, Basic Law.

36 Article 114, Basic Law .

37 Article 154, Basic Law.
} 
- formulate its own monetary and financial policies; ${ }^{39}$

- $\quad$ issue Hong Kong currency, backed by a 100 per cent reserve fund; $;{ }^{40}$ and

- $\quad$ retain its tax law regime. ${ }^{41}$

The Basic Law also prescribes the legislative systems which are to apply in the HKSAR. Article 8 provides that the laws in force in the HKSAR shall be the Basic

Law and guarantees the continuation of Hong Kong's Legal System:

The laws previously in force in Hong Kong, that is, the common law, rules of equity ordinances, subordinate legislation and customary law shall be maintained, except for any that contravene this Law, and subject to any amendment by the legislature of the Hong Kong Special Administrative Region.

Thus, the Common Law based on judicial precedents and the Ordinances that

$38 \quad$ Article 86, Basic Law.

39 Article 110, Basic Law.

$40 \quad$ Article 111, Basic Law. The legal tender in Hong Kong is the Hong Kong Dollar (HKD), which has been linked with the US Dollar (USD) at the fixed rate of approximately HKD7.80 to USD 1 since October 1983. The aim of this link has been to maintain long-term monetary stability. The linked exchange rate system requires both the stock and flow of the monetary base to be fully backed by foreign reserves. This means that any change in the monetary base is fully matched by a corresponding change in foreign reserves at a fixed exchange rate. There is no foreign exchange control in Hong Kong. The Hong Kong Monetary Authority ('HKMA') is the government authority with responsibility for maintaining currency and banking stability. When the three noteissuing banks (Bank of China (Hong Kong) Ltd, Standard Chartered Bank (Hong Kong) Ltd and The Hongkong and Shanghai Banking Corporation Ltd) issue banknotes, they are required by law to purchase certificates of indebtedness, which serve as backing for the banknotes issued, by submitting an equivalent amount of USDs at the above rate to the HKMA for the account of the Exchange Fund, a fund established to hold the backing to the note issue. HKD banknotes are therefore fully backed by USD deposits held by the Exchange Fund. Conversely, when HKD banknotes are withdrawn from circulation, certificates of indebtedness are redeemed and the noteissuing banks receive back an equivalent amount of USDs from the Exchange Fund. See Hong Kong Monetary Authority, Guide to Hong Kong Monetary and Banking Terms ( $3^{\text {rd }}$ ed, $)(2006)$ at: $<$ http://www.info.gov.hk/hkma/eng/public/ghkmbt/BT_eng.pdf $>$ at 30 September 2007. See, also, Greenwood, John, Hong Kong's Link to the US Dollar (Hong Kong University Press, Hong Kong, 2008). 
were in force before 1 July 1997 remain applicable after the transfer of sovereignty to China. One significant formal change was made to the judicial appeals system. The Hong Kong Court of Final Appeal (CFA) was established to replace the Judicial Committee of the Privy Council in the United Kingdom ('UK') as the court of final adjudication. ${ }^{42}$

The Basic Law, allows, but does not mandate, significantly enhanced democratization within the HKSAR. ${ }^{43}$ This political reform process has essentially stalled since $2004 .^{44}$ It is widely expected, however, that reform will eventually come.

The Basic Law itself promises that the ultimate aim is for both the CE of the HKSAR and all of LegCo to be elected by universal suffrage ${ }^{45}$ The Basic Law

42 Article 81, Basic Law.

43 See: Article 45 and Annex 1 of the Basic Law (re election of the HKSAR Head of Government (the Chief Executive)) and Article 68 and Annex 2 of the Basic Law (re election of the HKSAR Legislative Council (LegCo)).

44 On July 1, 2003, over 500,000 people marched peacefully through Hong Kong's streets to protest at the less than optimal performance of the second (Beijing-appointed) HKSAR Government led by C.H. Tung. All agree that this was a major political turning point for Hong Kong. Several of Mr Tung's Ministers (called Principal Officials) stepped down after the march - and he himself resigned early in 2005, to be replaced, for the balance of his term, by his Chief Secretary (and second in charge) Donald Tsang. In April 2004, the National People Congress Standing Committee (NPCSC) in Beijing controversially used their power under Article 158 of the Basic $\underline{\text { Law }}$ to issue an interpretation to the effect that no significant democratization for the selection of the CE in 2007 nor for the 2008 LegCo elections would be allowed by Beijing. These events including the use of Article 158 - are reviewed in Cullen, Richard, The Rule of Law in Hong Kong (monograph) at: http://www.civic-exchange.org/publications/2005/rolawe.pdf. For a comprehensive analysis of the development and consolidation of Hong Kong's system of nonelected government, see: Ghai, op. cit. note 22. See, also: Goodstadt, Leo F., Uneasy Partners (Hong Kong University Press, Hong Kong, 2005); and Miners, Norman, The Government and Politics of Hong Kong ( $5^{\text {th }}$ ed.) (Oxford University Press, Hong Kong, 1991). 
implies that some level of significant advancement towards that goal might have been expected by $2007 .{ }^{46}$ As matters have transpired, there has been no significant advancement by 2007 , leaving the highly limited form of democracy outlined above in place.

The scope for some level of significant reform of the system for choosing the CE of the HKSAR has been enhanced following the announcement, in December, 2007, by the National People's Congress Standing Committee (NPCSC) of the PRC, of a conditional timetable for the introduction of universal suffrage within the HKSAR. The NPCSC made the announcement in Beijing in late December, 2007. The NPCSC said that universal suffrage could be implemented in time for the CE election in 2017. This proposal is conditional in that its implementation depends all of the conditions in Annex I of the Basic Law being satisfied including the securing of a two-thirds majority, supporting vote in LegCo. The scope for some level of significant reform of the LegCo electoral system (in addition to possible CE election reform) has also emerged from the official discussion following the NPCSC decision of December 2007. It seems clear from these discussions that the NPCSC, while ruling out universal suffrage for LegCo in 2008 and 2012 will countenance such a reform for the LegCo elections 
due in 2020 (subject to compliance with the provisions of Annex II in the Basic Law). ${ }^{47}$

The NPCSC announcement of this timetable was much more solemn than celebratory: the HKSAR was soberly encouraged to appreciate this important dispensation. That said, December 29, 2007 may still be remembered in history as the first day on which the CCP ever agreed to a level of increased Westernstyle democracy anywhere within its borders. ${ }^{48}$

47 See, Yeung, Chris, Beijing keen to keep edge over democrats, Sunday Morning Post, January 6 , 2008, 10 .

The NPCSC's decision, made public on December 29, 2007, followed the submission of a Report to the NPCSC in accord with the second Article 158 Interpretation (see note 44 above) by the CE in mid-December, 2007. This Report followed on from the issuance of a Green Paper on Constitutional Reform by the HKSAR Government and resulting consultations (Public Consultation on Constitutional Development, at: http://www.cmabgpcd.gov.hk/en/consultation/index.htm). See: Wong, Albert, Leung, Ambrose and Fung, Fanny W. F., Tsang's 2020 Vision, Sunday Morning Post, December 30, 2007, A1; Wong, Albert, Leung, Ambrose and Cheung, Gary, 2017 suffrage goal hinges on progress by 2012, HK told, Sunday Morning Post, December 30, 2007, A2; Ching, Frank, Now comes the hard work on elections, South China Morning Post, January 1, 2008, A10; Yeung, Chris, Beijing keen to keep edge over democrats, Sunday Morning Post, January 6, 2008, 10; and Cheung, Anthony B.L., Take 2017 as a positive target for democratization, Newsletter, January, 7, 2008. 


\subsection{REVENUE REGIME EVOLUTION}

\subsection{FINANCING THE COLONIES}

A heavy reliance on land-related revenues (wherever possible) within the British Colonies was well established as a key public finance measure by the early $19^{\text {th }}$ century. In essence, this approach sought to fund the running of many British Colonies by relying, primarily or significantly, on the disposal of (appropriated or discount-purchased) Crown land by Colonial Governments. ${ }^{49}$ It appears the policy was developed in London through the Colonial Office in response to the unhappy outcome arising from attempting to impose long-distance, Londondevised taxes in the British-American Colonies in the second half of the $18^{\text {th }}$ century. ${ }^{50}$

From a London point of view, these long-distance taxes were originally seen to be necessary to help cover local colonial expenditure in America on, for example, maintaining local military garrisons and the provision of public infrastructure in

49 See: Hooper, Keith C., Substance but not Form: Capital Taxation and Public Finance in New Zealand (1840 - 1859) at: www.findarticles.com/p/articles/mi qa3933/is 200311/ai n9326384/; and, Harris, R. Cole, Making Native Space: Colonialism, Resistance and Reserves in British Columbia (University of British Columbia Press, Vancouver, 2002) Chapter 1. See, also, Pierce, Steven. Farmers and the State in Colonial Kano: Land Tenure and the Legal Imagination. (Indiana University Press, Bloomington, 2005).

The position of Secretary of State for the Colonies was first established in 1768 in response to restiveness in the American Colonies. By 1801, after the loss of those colonies a new position of Secretary of State for War and the Colonies was established. In 1854 a fully separate Colonial Office was established under the now Secretary of State for the Colonies. See, Secretary of State for the Colonies, at: http://en.wikipedia.org/wiki/Secretary_of_State_for_the_Colonies. 
the American Colonies. This tax approach culminated in the loss of those colonies and the establishment of the USA. ${ }^{51}$

Another feature of colonial financing within the British Empire was a general avoidance of direct taxes (on, for example, salary, wages, profits or rents). This was especially the case in the smaller British Crown Colonies (such as Hong Kong). ${ }^{52}$ It was felt that such taxes required an element of understanding as to why they were needed on the part of the individuals subject to said taxes and this understanding was usually widely lacking. ${ }^{53}$ This meant that there was a strong preference for collecting revenue from indirect taxes (for example, Customs Duties, Excise Duties) business licence fees, certain specific taxes (for example, Stamp Duties) - and from land sales and land usage charges. ${ }^{54}$ Ideally, these post American Revolutionary War, British colonial revenue systems were meant to be: colony-confined (no extra-territorial taxation); self supporting (but not "Mother-Country" supporting); and crafted to suit the local political-economy. ${ }^{55}$ Where the "chief economic consideration" of a colony was trade with foreign countries then, it was argued, all trade-related taxes (especially, Import Duties)

\footnotetext{
51 See, American History Series: Britain Says No to 'No Taxation Without Representation, at: http://www.voanews.com/specialenglish/archive/2007-12/2007-12-05-voa2.cfm.

52 Reinsch, Paul S. Colonial Administration (MacMillan, London, 1912), 92ff (Available at: http://books.google.com/books?id=uZJKdzOZ0pAC\&pg=PA98\&lpg=PA81\&dq=colonial+taxatio n\&output=html\&sig=80hpdTPdUtPuIQH1bClQdH57BQY.

$53 \quad$ Ibid.

$54 \quad$ Ibid.

$55 \quad$ Ibid
} 
should be kept very low or be non-existent. In some colonies (in Africa and the Pacific) poll taxes were used, also. ${ }^{56}$

As various British Colonies developed more sophisticated economies - including more taxpayers blessed with a capacity to "understand" - a greater use of income-type (direct) taxes began to be imposed. By 1922, an InterDepartmental-Committee in London had devised a "Model Ordinance" for imposing Income Tax. This Model Ordinance drew on older precedents developed within the Australian and New Zealand colonies together with more recent laws from Canada and Australia. ${ }^{57}$

\subsection{REVENUE REGIME DEVELOPMENT IN HONG KONG}

\subsubsection{The Initial Phase}

Brown and Loh explain that the early development of what remains, to this day, a fundamental aspect of the operation of the Hong Kong Revenue Regime - landtransaction revenues - derived from the fact that the very first Hong Kong Governments were able to assert that they owned the superior title to all land. ${ }^{58}$ As noted earlier, British Hong Kong, initially (from 1841/42) consisted only of Hong Kong Island. The Kowloon Peninsula was added in 1860. The small

$56 \quad$ Eichelgrun, G., Income-Tax in British Colonies, (1948) 58 The Economic Journal, 128.

$57 \quad$ Ibid.

58 Brown, Stephen and Loh, Christine, Hong Kong: The Political Economy of Land (2002) 8-9 $<$ http://www.civicexchange.org/publications/2002/The\%20political\%20economy\%20of\%20land.pdf > at 30 September 2007. 
number of existing residents appear to have been mainly fishermen and families who lived on their boats plus some farmers. In the eyes of the colonizers, it seems these locals lacked any firm claims over dry land areas. ${ }^{59}$ (When the British acquired the New Territories in 1898, the land rights of indigenous, long settled farming communities were recognized. ${ }^{60}$ )

Brown and Loh maintain that:

At the outset, the administration decided that any interests in land sold to the private sector should be leasehold interests, rather than the freehold interests that could have been offered. The only practical way of releasing land was through auction and the first auctions were held in the 1840's. Commentators were already describing the frenetic bidding from the merchants and volatility of the market. To prevent abuse, the leasehold interests were granted with terms attached limiting the types of usage, which eventually became the key determinant in assessing the economic value of a piece of land.

In the initial years after the founding of the colony, there was some discussion back and forth with Whitehall over what interests in land should be sold, whether freehold land should be released, and whether auction was the correct approach. Some twenty years after Hong Kong's founding, an expedient decision was made. The British garrison in Hong Kong was not to be funded from Whitehall any longer, and government ownership of the land market in Hong Kong was proving to be a good revenue generator to help pay expenses. ${ }^{61}$ less than 7,500. See, Tsang, Steve, A Modern History of Hong Kong (Hong Kong University Press, Hong Kong, 2006) 18. Hong Kong $\left(2^{\text {nd }}\right.$. Ed.) (Hong Kong University Press, Hong Kong, 2008) Chapters 1 and 2. 
Property rates were imposed on the new property (leasehold) owners also, almost from the outset. ${ }^{62}$ Another early (and continuing) impost introduced in Hong Kong was Stamp Duty, in $1866 .{ }^{63}$ The collection of Estate Duty effectively came to an end in the HKSAR in early 2006 but prior to this it had applied (albeit just on property situated within Hong Kong) from fairly early in the $20^{\text {th }}$ century. ${ }^{64}$ Excise Duties (for example on hydrocarbon oil; alcoholic drinks and tobacco products) have also been imposed in Hong Kong for a long time. ${ }^{65}$ An Entertainments Tax applied from $1930 .{ }^{66}$ Hong Kong was established as a Free Port, however, so there have never been any duties on goods entering Hong Kong. ${ }^{67}$ In fact, as soon as Captain Charles Elliot took possession of Hong Kong Island for the UK in January 1841 , he proclaimed it to be a Free Port. ${ }^{68}$

Another particularly grim source of revenue arose from fees and charges which applied to the opium trade. (It was primarily disputation with China about Britain's right to export opium that led to the First Opium War and the seizure of

$62 \quad$ Nissim, op. cit note $60,11$.

63 Stamp Duty Ordinance (1866) - today, Stamp Duty Ordinance (1981). See, also, Lou, Jianbo, Hong Kong: An Offshore Financial Centre in the Far East-Its Present and Future (1998) 52 Bulletin for International Fiscal Documentation, 297.

64 Estate Duty Ordinance (1932). See, too, Abolition of Estate Duty - Inland Revenue Department Press Release, at: http://www.ird.gov.hk/eng/ppr/archives/07042501.htm.

65 See, Hong Kong: Customs Excise, at: http:/www.gov.hk/en/about/abouthk/factsheets/docs/customs.pdf

66 Entertainments Tax Ordinance (1930) and see, Hong Kong Legislative Council Minutes, March 27, 1941, at: http://www.legco.gov.hk/1941/h410327.pdf.

67 Minutes, ibid. See, also, Hong Kong, at: http://en.wikipedia.org/wiki/Hong_Kong.

$68 \quad$ Tsang, op. cit. note 59, 21. 
Hong Kong Island. ${ }^{69}$ ) For many decades after 1841 the Hong Kong Government benefited from this trade. As late as 1917, up to one third of all revenues in Hong Kong were related to opium trading activities. ${ }^{70}$

Another early source of revenue came through taxes and fees related to gambling. The Hong Kong Jockey Club (HKJC) (previously the Royal Hong Kong Jockey Club) was founded in 1884 to run and promote horse racing. In the post-WW II period it has become both Hong Kong's biggest single taxpayer and also Hong Kong's most significant charitable contributor. It came to acquire monopoly rights over all legal gambling activities in Hong Kong. The HKJC operates on a non-profit basis. ${ }^{71}$ Betting Duties were introduced by $1931 .{ }^{72}$

Tho'Mas, Kristianna, Opium War of 1838-42: How Britain Stole Hong Kong from China, at: http://www.hartford-hwp.com/archives/55/044.html.

La Motte, Ellen N., The Opium Monopoly (MacMillan, New York) 1920) Chapter 7 (Hong Kong) at: http://www.druglibrary.org/schaffer/History/om/om7.htm (quoting official records). Ellen La Motte, born in 1873 in Louisville, Kentucky, became a battlefield-nursing activist and journalist during WWI prior to spending some years, post-war, in East Asia. She wrote extensively, and not un-controversially, on a wide range of social and political issues related to China and Chinese people, in particular. She became key advocate during the inter-war years, for the ending of the legal trade (frequently by governments) in opium and its derivatives. For a useful short overview of her remarkable, activist-life, see, Sugiyama, Keiko, Ellen N. La Motte, 1873-1961: Gender and Race in Nursing (2006) 17, Japanese Journal of American Studies, 129 (available at: http://wwwsoc.nii.ac.jp/jaas/periodicals/JJAS/PDF/2006/No.17-129.pdf). This article also provides a helpful listing of many of LaMotte's books and journal articles.

See, Hong Kong Jockey Club - History, at: http://www.hkjc.com/english/corporate/corp history.asp; and Hong Kong Jockey Club, at: http://en.wikipedia.org/wiki/Hong_Kong_Jockey_Club. 


\subsubsection{Income Tax Commences}

The first moves to introduce an income tax in Hong Kong came in December 1938 when Governor Northcote established the Taxation Committee to look at the possible adoption of income taxation in the jurisdiction. The committee recommended that an Income Tax be introduced. ${ }^{73}$

In September 1939, when the UK declared war on Germany, the Governor pushed ahead with his plans to introduce an Income Tax in order to contribute to Britain's war effort. An Income Tax Bill designed to establish a single tax on all income was prepared. The Chinese business community was "vehemently opposed in principal to any form of tax on income. In particular, they were opposed to any tax at all on business profits." Their stance quickly attracted the support of the expatriate business community. ${ }^{74}$

While the Governor could constitutionally override dissent within LegCo, he chose, instead, to convene a War Revenue Committee in order, "to cement the private sector's position that it was only because of the war that extra revenue was required." ${ }^{75}$ It was also argued that British sensitivity was heightened by the fact that the revenues "were intended not to be spent for the colony's own direct

73 Littlewood, Michael, Taxation Without Representation: The History of Hong Kong's Troublingly Successful Tax System (2002) British Tax Review 212. See, also, Littlewood, Michael, Tax Reform in Hong Kong in the 1970s: Sincere Failure or Successful Charade? in Tiley, John (ed.), Studies in the History of Tax Law (Hart, Oxford, 2004).

74 Littlewood, 2002, ibid.

$75 \quad$ Ibid. 
benefit, but to be transferred to Britain." ${ }^{76}$ This committee proposed only a "partial income tax" and while the colonial authorities "regarded the committee's proposal as barely adequate, even as a temporary wartime measure," they nonetheless adopted the proposal. ${ }^{77}$

The War Revenue Ordinance (1940) created a system of schedules, establishing three separate taxes on different categories of income - a Property Tax with a flat rate, a Salaries Tax with progressive rates and a Profits Tax with a flat rate for corporations and progressive rates for unincorporated firms. The Ordinance exempted all offshore income from taxation. ${ }^{78}$

In drafting the Ordinance, the War Revenue Committee copied, it is said, the schedular British income tax system introduced by Prime Minister Addington in 1803, despite the fact that the British system itself had been reformed in 1910 to base tax liability on a taxpayer's total income. In Littlewood's view, the committee chose to copy a system which Britain, "had effectively discarded thirty

\footnotetext{
$76 \quad$ Ibid.

$77 \quad$ Ibid.

78 Ibid. This approach was entirely consistent with the $19^{\text {th }}$ century tax policy - favouring sourcedbased taxation in the colonies - adopted by the British as their Empire developed. See, Barker, William B., Expanding the Study of Comparative Tax Law to Promote Democratic Policy: The Example of the Move to Capital Gains Taxation in Post-Apartheid South Africa (2005) 109 Pennsylvania State Law Review, 101, at 111. See, also Easson, 2006, op. cit. note 1.
} 
years earlier" because the representatives of business believed the separated schedular structure would reduce the possibility of future increases in tax rates. ${ }^{79}$

The newly established tax system met significant criticism from the authorities in Britain and the War Revenue Committee was reconvened the following year. The War Revenue Ordinance (1941) replaced its predecessor and introduced small changes, including the introduction of an additional Interest Tax and an increase in the maximum rate of taxation. ${ }^{80}$ The new Ordinance, however, was short-lived. In December 1941, six months after its adoption, Hong Kong was occupied by the Japanese.

The new 1947 tax legislation, the Inland Revenue Ordinance (IRO) "retained the basic schedular structure and the restricted territorial ambit of the War Revenue Ordinance" of 1941. Again, there were separate schedules for salaries, profits and interest originating in Hong Kong (with low tax rates). The new Ordinance differed in one important sense from its predecessor in that it introduced a system of "Personal Assessment" whereby an individual could choose to pay tax

79 Littlewood, 2002, ibid. The perception amongst the business elites that the reliance on separate schedules would help forestall future tax increases may not have been well founded, however. Significant discrepancies in tax rates applicable to personal exertion, corporate and income from property have characterized Australia's uniform tax system for almost 70 years now, for example. This level of discrepancy has produced strains and continues to attract criticism: "A large gap between the top personal income tax rate and the company tax rate creates an incentive to redefine personal income as company income" (Shorten, Bill, An Alternative Vision for AustraliaBuilding our Nation, at: http://www.fabian.org.au/library/event_papers_2005/1118116108_23303.html). Despite this long history of significant tax rate divergence, the Australian tax system has remained politically workable over many decades, however. See also, Sorensen, Peter, Birch, The Nordic Dual Income Tax - In or Out? at: http://www.econ.ku.dk/pbs/diversefiler/oecddual.pdf.

$80 \quad$ Littlewood, ibid. 
(at progressive rates) on his or her total income, rather than use the strict schedular system. ${ }^{81}$

Since 1947, the IRO has been formally re-examined on three occasions, in 1954, 1968, and 1976, by Review Committees. Yet, no major alterations have been made to the taxation system. In 1984, an amendment was finally introduced whereby "interest income of all types of taxpayers 'arising through or from the carrying on' of the taxpayer's business in Hong Kong was deemed to arise in Hong Kong". The amendment received a hostile reception from the business community, however, and was quickly repealed in $1986 .^{82}$

The 1976 review committee made perhaps the most significant recommendation for reform when it suggested that Income Tax should be assessed on total income, eliminating the separated schedular system of assessment. In 1978, the Government was still considering this recommendation but, by the following year, the authorities had decided not to pursue such a reform. The Government's decision was again, it would seem, influenced by the business community's "firm and vociferous opposition to tax reform." ${ }^{83}$

\footnotetext{
$81 \quad$ Ibid.

$82 \quad$ Ibid.

83 Littlewood-2004, op. cit. note 73.
} 


\subsubsection{Overview of the Current Revenue Regime}

As noted above, the British established Hong Kong as a Free Port which meant that goods could enter and leave free of any customs or similar duties. This continues to be the case today. Indeed, Hong Kong has long prided itself on its low and simple, Tax Regime. ${ }^{84}$ Direct taxes applied to business profits and earned income still remain amongst the lowest in the developed world. ${ }^{85}$

The Tax Regime in the HKSAR today encompasses the following key features: ${ }^{86}$

- A narrow taxation base;

- Low taxation rates;

- Separate schedules applying separately identified taxes to different classes of income - no general income tax.

- No taxation of income derived from outside of Hong Kong regardless of the residence status of the taxpayer (source-based taxation).

- Simple and relatively stable taxation laws;

- Retention of Stamp Duties in the system;

- Almost no use of Double Taxation Treaties (DTTs); ${ }^{87}$

- Comparatively constrained government spending;

$84 \quad$ Reynolds, Alan, Hong Kong's Excellent Taxes, at: http://www.cato.org/pub_display.php?pub_id=3793.

85 See table at: $h$ htp://www.forbes.com/global/2005/0523/024chart.html. See also, table at: http://invest.vic.gov.au/About+Melbourne/Doing+Business+in+Melbourne/Taxation.htm.

86 This outline of the current Hong Kong revenue system summarises and updates a more comprehensive review of the taxes applying in the HKSAR, which can be found in Cullen, Richard, Revenue Law in Hong Kong: The Future in Wacks (ed.) The New Legal Order in Hong Kong (Hong Kong University Press, Hong Kong, 1999) Chapter 12.

87 Hong Kong's approach to DTTs has been changing since 1997, however, see discussion below 
- Very little government borrowing;

- Infrequent (until recently) deficit budgeting; and

- Massive accumulated fiscal reserves.

The main taxes imposed (using separate schedules) by the IRO are:

- Profits Tax;

- Salaries Tax; and

- Property Tax.

Profits Tax, the most important tax in terms of revenue raised, is imposed by Part IV of the IRO. The crucial practical and legal issue is source: only profits which can be shown to have (or which, in a few limited cases, are deemed to have) a source in Hong Kong are subject to profits tax. As the discussion above demonstrates, the adherence to this source rule has been driven, to a large extent, by the desire of businesses, at all levels, to use Hong Kong as a base from which to operate without incurring tax on any offshore operations. ${ }^{88}$ The operation of the source principle in Hong Kong has been the subject of much

88 The motivation for retaining a source-based taxation system dates back to Hong Kong's original status as a Free Port. This status meant that Hong Kong was a place where trading business could be done, in the $19^{\text {th }}$ century, without need to be concerned about taxation, either through Customs Duties or Income Tax. As the need for some sort of Income Tax was grudgingly conceded just prior to and after World War II (see discussion above) the impact of the new Tax Regime was restricted from the outset by the incorporation of a source rule restricting the application of Profits Tax to profits arising within Hong Kong. This sourced-based taxation regime has remained highly attractive to business as Hong Kong has, since the $19^{\text {th }}$ century, made the transition from trading port, to manufacturing centre to, nowadays, a sophisticated, mostly service-based economy. See, further, below and also, Easson, 2006, op. cit. note 1. 
litigation. Overall, its application has, historically, worked fairly well, however. ${ }^{89}$

Hong Kong remains, in practice, the last remaining first-world jurisdiction to rely so heavily on a rule which excludes from the tax-net all profits which can be shown to have arisen outside of the jurisdiction. ${ }^{90}$

\author{
Salaries Tax, which is imposed by Part III of the IRO, is also an important funding \\ source. Salaries Tax applies at progressive rates but it is subject to fixed
}

89 Halkyard, Andrew, The Hong Kong Tax Paradox (1998) 8 Revenue Law Journal 1, 20. This article contains a useful summary of the key cases on source.

Wong, Antonietta, Unpublished Thesis Manuscript (2005): "Jurisdictions using the territorial system to varying degrees include Bolivia, Costa Rica, El Salvador, Guatemala, Kenya, Malaysia, Nicaragua, Panama, Paraguay, Singapore and Uruguay (see Thuronyi, Victor, Comparative Tax Law (Kluwer Law International, The Hague, 2003) 287). Singapore uses a form of source-based taxation whereby income 'accruing in or derived from Singapore or received in Singapore from outside Singapore' is taxed. But the remittance basis has been effectively abolished in many situations. From 1 June 2003, all foreign-source dividends, branch profits and services income received by a resident company are exempt from tax if the following conditions are met: (A) the income is received from a foreign jurisdiction with a corporate tax rate of at least 15 per cent in the year the income is received in Singapore; and (B) the foreign income has been subject to tax in the jurisdiction from which it was received. From 1 January 2004, all foreign-source income received by resident individuals is exempt from tax, except through a partnership in Singapore. Nonresidents are taxed on income accrued in or derived from Singapore. See, Tan, Angela and Tan, How Teck, Singapore Master Tax Guide 2006/07 (25 ${ }^{\text {th }}$ ed,) (CCH, Singapore, 2006). See, also, Halkyard, Andrew and Phua, Stephen, Lye Huat, Common Law Heritage and Statutory DiversionTaxation of Income in Singapore and Hong Kong (Paper presented at the University of Hong Kong-National University of Singapore Law Symposium, Faculty of Law, University of Hong Kong, 11-12 December 2006) for a discussion of taxation of income in Singapore. Malaysia uses another version of territorial or domestic source-based taxation. Tax is imposed on income 'accruing in or derived from Malaysia or received in Malaysia from outside Malaysia'. However, income remitted by resident companies investing overseas is exempt from tax except for those carrying on banking, insurance, air and sea transport operations which are taxed on a worldwide basis. From 1 January 2004, income remitted from overseas to Malaysia and received in Malaysia by resident individuals is also exempt from income tax. Non-residents are taxed on income accrued in or derived from Malaysia, but not on income received in Malaysia from outside sources. See, CCH Tax Editors, Malaysia Master Tax Guide 2006 (23 $3^{\text {rd }}$ ed, $)(C C H$, Kuala Lumpur, 2006). South Africa only replaced its (UK-colonial) sourced-based tax system with a world-wide, residence based tax system following the collapse of the Apartheid system and the swearing in of South Africa's first non-racial Government in 1994 (see, Barker, William B., Expanding the Study of Comparative Tax Law to Promote Democratic Policy: The Example of the Move to Capital Gains Taxation in Post-Apartheid South Africa (2005) 109 Pennsylvania State Law Review, 101). 
percentage "maximum" or "standard" rate on total taxable income. ${ }^{91}$ The Salaries Tax system is also source-based but the specified source rules in Part III (backed by case law and Departmental Interpretation and Practice Notes (DIPNs)) have meant that source is less of an issue than with Profits Tax. ${ }^{92}$

The final schedular tax imposed by the IRO is Property Tax, which applies at a flat rate on rent received, less a statutory allowance of $20 \%$ for repairs and maintenance. Corporations owning property are exempt from property tax - they pay Profits Tax on rents received instead.

Stamp Duties imposed by the SDO raise around $10 \%$ of revenue depending very much on activity in the real estate and share markets. ${ }^{93}$ Betting Duty (on horserace, lottery and football betting) imposed by the Betting Duty Ordinance (1950), normally raise less than $10 \%$ of total revenue. Estate and Gift Duties used, until recently, to be imposed by the Estate Duties Ordinance (1950) but these duties have recently been abolished. ${ }^{94}$ The yield from these duties has

$91 \quad$ 2005/2006 Hong Kong Budget - Tax Rates Card, at: http://www.pwchk.com/home/eng/hktax_rates_card_2005.html. It is often said that Hong Kong applies a "flat tax" to salaries and wages. A true flat tax applies a fixed (flat) rate of tax typically on all income from zero-plus-one-dollar of income to infinite-dollars of income. The Hong Kong salaries tax regime clearly (based on the description above) does not apply a flat tax in this way. The term "flat tax" is, however, often used as a (rather inaccurate) short-hand term in place of the more correct "maximum" or "standard" tax rate.

92 Cullen, op. cit. note 86. See too, DIPN 10 The Charge to Salaries Tax at: http://www.ird.gov.hk/eng/pdf/e dipn10.pdf.

93 See, Cullen, ibid; and Hong Kong Yearbook 2004- The Economy at, http://www.info.gov.hk/yearbook/2004/en/03 05.htm.

94 See, Hong Kong - Abolition of Estate Duty, at: http://www.bakernet.com/NR/rdonlyres/3834909F-DAF6-403E-B6E9- 
been quite low for some time. ${ }^{95}$ Other comparatively minor sources of revenue include: property rates, various fees and duties (such as Excise Duties on tobacco, alcohol and petroleum products) utility charges and vehicle-related imposts. ${ }^{96}$ More significant, non-taxation sources of revenue include: investment and interest income (on fiscal reserves - see below), and direct land-transaction revenues, which are discussed in some detail below. ${ }^{97}$

Despite this low tax regime, Hong Kong has still managed to provide public housing on a massive scale, to finance excellent transport and communications systems and comparatively sound education and health systems. ${ }^{98}$ At the same time, it has managed to amass public foreign currency reserves of over $\$$ US150 billion. ${ }^{99}$

ED3DC84F088A/38385/HKAbolitionofEstateDuty.pdf. The argument is that, by becoming one of the first jurisdictions in East Asia to remove Death/Estate/Gift Duties, Hong Kong will: help small Hong Kong businesses with cash flow problems; encourage increased location of assets in Hong Kong; and strengthen the HKSAR's position as a location for regional fund managers (see, Abolition of estate duty helps promote HK's asset management business, at: http://www.fstb.gov.hk/eng/sfst/fstb19.html.)

The Hong Kong Institute of Certified Public Accountants estimated that the EDO typically generated less than $1 \%$ of total government revenues (see, Estate Duty Review Consultation Document, at: http://www.hkicpa.org.hk/professionaltechnical/taxation/submissions/submission_201004.pdf.)

Hong Kong Yearbook 2004- The Economy at, http://www.info.gov.hk/yearbook/2004/en/03 05.htm.

Ibid.

Cullen, op. cit. note, 86 .

Foreign Reserves, The Economist, January 24, 2008, at: http://www.economist.com/markets/indicators/displaystory.cfm?story id=10568635. These fiscal reserves are known, officially, as the Exchange Fund (see, too, footnote 40). The Exchange Fund, today, essentially comprises: (A) the fiscal reserves (money saved from revenues raised but not spent over previous decades) of the Government's General Revenue Account (roughly $40 \%$ of the Exchange Fund); and (B) the balance of government foreign currency reserves which back the Hong Kong Dollar (HKD) (roughly 60\% of the Exchange Fund). (Until 1998, a separate Land 
The explanation for this apparent fiscal miracle has a number of facets. First, the

Hong Kong Government has had access to a revenue source rarely available in

the modern age to most Governments: land. Hong Kong is not large at around

1,000 square kilometres. And, until relatively recently, one had to live and work

within this small area if one wished to make a life based in Hong Kong. ${ }^{100}$ From

its inception, British Hong Kong did not allow (virtually) any sale of freehold

Fund was also retained by the Hong Kong Government. In that year, the assets of the Land Fund were merged with the Exchange Fund - although the uses to which the Land Fund could be put remained restricted (primarily to capital expenditure). See, Merger of Land Fund Assets into Exchange Fund, at: http://www.info.gov.hk/hkma/eng/press/1998/981117e.htm.) The Exchange Fund is managed by the Hong Kong Monetary Authority (HKMA). The HKMA also manage the quasi-currency board pegging of the HKD to the US Dollar (USD). That part of the Exchange Fund backing the HKD covers about $240 \%$ of all HKD notes and coins in circulation plus certain other securities. It only covers about $30 \%$ of all HKD deposits, however. A Currency Board fixes the exchange rate of Currency A (the HKD in this case) to an "anchor", much stronger Currency B (the USD in this case) at a fixed rate and promises to convert cash and equivalent holdings of Currency A to Currency B at any time at the fixed rate (see,

http://users.erols.com/kurrency/intro.htm). It is argued that Hong Kong does not have a real Currency Board system because, amongst other things: (a) the HKMA manages the HKD other than in accord with strict Currency Board principles; and (b) the HKMA (unlike a true Currency Board) also operates like a Central Bank, in certain respects - by regulating the banking and financial systems. See, further, An Introduction to the Hong Kong Monetary Authority, at: http://www.info.gov.hk/hkma/ar2004/english/summary/summary eng.htm; Hong Kong Yearbook 2004 - Exchange Fund, at: http://www.info.gov.hk/yearbook/2004/en/04 12.htm; Lo, Chi, The Demise of the Hong Kong Dollar, at:

http://www.chinabusinessreview.com/public/0303/commentary.html; and Greenwood, John, Hong Kong's Link to the US Dollar (Hong Kong University Press, Hong Kong, 2008). The recent, unprecedented heavy reliance of the HKSAR Government on deficit financing (discussed in the text) has been paid for out of the Government's fiscal reserves in the Exchange Fund. Unlike in the case of accessing additional revenues through extra taxation, where the approval of LegCo is mandatory, the HKSAR Government can access the fiscal reserves without being compelled to seek LegCo approval.

Since the 1980s, Hong Kong entrepreneurs have been transferring their manufacturing and other businesses to the Mainland (and especially to the adjacent Province of Guangdong). Since the 1990s, numbers of individuals have begun to commute to Hong Kong from the now vast city of Shenzhen directly across the border. Shenzhen has seen its population grow from under 100,000 to well over 7 million plus in less than three decades. See, http://pdf.sznews.com/szdaily/2001/0418/1.htm. 
land. ${ }^{101}$ All land was made available as leasehold land. Moreover, the practice grew of restricting the availability of land for development. This tended to drive up the price of land (towards the upper limits of what the market would accept) and revenue receipts. ${ }^{102}$

The reliance on land-related revenues in Hong Kong follows a pattern, discussed above, established by the British by the early $19^{\text {th }}$ century. In essence, this system sought to fund the establishment of new British Empire Colonies by relying, primarily or significantly, on the disposal of (appropriated or discountpurchased) Crown land by Colonial Governments. ${ }^{103}$

101 The Hong Kong Anglican Cathedral occupies freehold land. Landholders in the New Territories have also historically been allowed, by the Government, to enjoy certain special rights to land based on ancestral rights which derive from membership of long established communities in the New Territories. See, further, Nissim, op. cit. note 60. British rule, the Hong Kong Government derived some $32 \%$ of total revenues from land-related transactions (including sales, lease modification premiums and Stamp Duties - but not including Profits Tax and Salaries Tax arising directly from the real estate sector) see, Loh, Christine, The Government's High-Land-Price Policy: Can Hong Kong People Afford it? at: http://www.citizensparty.org/housing/landpric.html. See, too, Bell, Daniel A, Hong Kong's Transition to Capitalism, at: http://www.findarticles.com/p/articles/mi qa3745/is 199801/ai n8787332. This heavy reliance on land transaction revenues in Hong Kong has, it would seem, been developed and introduced as a matter of practice - under the influence of the Colonial Office in London. It has been found to work, so the practice has developed further. The practice bears some resemblance to the theories propagated by Henry George, the $19^{\text {th }}$ century American economist and social reformer who long advocated the introduction of a single tax on the unimproved value of all land to replace all other taxes. See, http://www.answers.com/topic/henry-george. See also, Smith, Julie P., Taxing Popularity: The Story of Taxation in Australia (Federalism Research Centre, Canberra, 1993) 1824. A Henry George follower, Lizzie Magie, created the board game Monopoly in 1904 to demonstrate his theories (http://www.answers.com/topic/henry-george). Zealand (1840 - 1859) at: www.findarticles.com/p/articles/mi_qa3933/is 200311/ai_n9326384/; and, Harris, R. Cole, Making Native Space: Colonialism, Resistance and Reserves in British Columbia (University of British Columbia Press, Vancouver, 2002) Chapter 1. 
The entire land management system has become self-reinforcing and, arguably, financially addictive (for the Government). ${ }^{104}$ Government land policy has fostered one of the highest population densities of any major city in the world. Hong Kong has more skyscrapers, at over 7,400 , than any other city on the planet, including New York. ${ }^{105}$ The majority of these are residential. This density has allowed the provision of first rate transport and communications systems with greater speed and lower cost than would otherwise have been the case. It has also, originally incidentally and now as a matter of policy, left the greater part of Hong Kong's total area either subject to low density use or zoned as public (mostly park) areas. ${ }^{106}$

Government policy has, predictably, had a significant upward impact on the price of land. The Government, historically, could always, it seemed, rely on accessing additional revenue by leasing land long-term (as the sole supplier) into a market with ever rising prices. The Government also takes a large fiscal bite from many secondary market transactions. Strict usage conditions are stipulated in each government lease. If a developer purchases an old building wishing to

104 Brown, Stephen, Fung, Edward K. W., Loh, Christine, Uebergang, Kylie and Xu, Stephen, The Budget and Public Finance in Hong Kong, 34-35, at: http://www.civicexchange.org/publications/2003/BudgetReport.pdf.

Tall Buildings, The Economist, April 9, 2005, 90.

This does not mean that the Government has especially good "green" credentials. On the contrary, successive Hong Kong Governments have displayed almost a mania for land reclamation from Victoria Harbour and beyond and for massive road and bridge building projects, for example. See, further, Loh, Christine, Alternative Policy Address2005-2006, at, http://www.civicexchange.org/publications/2004/apa05e.pdf. The fact that Hong Kong has taken a very high density approach to building (thus maximising government land-related revenues) has, by accident more than design, left much of its land area comparatively under-developed or undeveloped. 
rebuild at say five times the height of the building to be replaced, the developer needs to obtain a variation to the purchased lease. To get this, the developer has to pay a substantial "land premium" to the Government. When one adds in the Profits Tax paid by developers and all the others involved in construction, transaction based Stamp Duties and Salaries Tax paid by those working in the sector, the HKSAR Government has continued to rely, in recent years, on land transaction related revenues for around $50 \%$ of its income. ${ }^{107}$

There are, of course, market limitations on just how high land prices may be pushed by a government - even within a comparatively closed system such as that which has operated in Hong Kong. That is, government cannot simply set any price for land it chooses. If a price is too high, then buyers in the market simply will not respond. Thus the Hong Kong Government has had experience with trying to sell commercial land where there were simply no takers. ${ }^{108}$ More recently, following the onset of the Asian Financial Crisis (AFC) in mid-1997 the Government found it difficult to sell plots for residential development. Subject to these fundamental constraints, successive Hong Kong Governments have played a significant role - over several decades - in creating conditions which have typically put upward pressure on land values.

107 Halkyard, Andrew, The Hong Kong Tax Paradox, (1998) 8 Revenue Law Journal, 1.

108 The Hong Kong Government experienced serious difficulties in selling (leasing) land for commercial / industrial use in East Kowloon in the past, for example (discussion with Leo Goodstadt, September 30, 2005). See, further, Goodstadt, op. cit. note 44, Chapter VI. 
On the day after the handover, on July 2, 1997, the AFC began, when the Thai currency, the Baht, collapsed. The AFC, combined with a range of other factors, triggered a huge collapse in asset values in Hong Kong. These other factors included: (a) competency problems within the new HKSAR Government; (b) a currency, the HKD, pegged to the USD via an adapted Currency Board system; ${ }^{109}$ and (c) "bubble-economy" property values established during the final years of British rule. ${ }^{110}$

Property prices began to collapse by 1998 , shortly after the AFC hit. By 2003 , at the height of the Severe Acute Respiratory Syndrome (SARS) health crisis, residential property prices had fallen by about $70 \%$ from their bubble-market peak. This, in turn, had a devastating impact on the revenue flow to the HKSAR Government. The Government came to rely, over a period of years (and for the first time in living memory) on substantial deficit financing to meet recurrent expenditure. ${ }^{111}$ Mass market residential property prices have recovered significantly since the low point in 2003 . Nevertheless, it is recognized that Hong

$109 \quad$ See footnote 99.

$110 \quad$ See footnote 102.

111 Crampton, Thomas, Hong Kong moves to curb deficit, International Herald Tribune, 9 January 2003, at: http://www.iht.com/articles/2003/01/09/a7 6.php). Note, this deficit spending has been funded by relying on Hong Kong's massive reserves rather than through borrowing, reducing any adverse credit-rating impact significantly. For a full review of the onset and impact of the SARS crisis in Hong Kong see, Loh, Christine and Civic Exchange (eds.) At the Epicentre: Hong Kong and the SARS Outbreak (Hong Kong University Press, Hong Kong, 2004). 
Kong's narrow (land revenue related) tax base is a serious systemic fiscal flaw which needs to be fixed. ${ }^{112}$

The Hong Kong Government has also historically been able to control expenditure quite effectively. Cultural-economic reasons provide an important part of the explanation for this. Briefly, Hong Kong people have long relied heavily on family and related networks to cope with a multitude of life's exigencies. Moreover, from the 1960s until the 1990s, Hong Kong maintained high economic growth rates sustaining full employment. Also important was the long established reluctance of the Government to introduce more comprehensive programmes to tackle endemic social justice deficiencies within Hong Kong. ${ }^{113}$

This combination of factors meant that the Government was put under (and placed itself under) significantly less pressure to develop a "welfare state" of the complexity typically encountered in most other developed economies. What evolved is a system which has been described as the "residual welfare state". ${ }^{114}$

112 See the HKSAR Government's acknowledgement of this problem, Hong Kong Yearbook 2004The Economy, Public Finance - Need to Broaden Tax Base, at: http://www.info.gov.hk/yearbook/2004/en/03_05.htm. See, too: the proposals put forward by the British Chamber of Commerce in Hong Kong at http://www.britcham.com/asp/ArticleDetail.asp?ArticleId=259; and Brown, Stephen, Fung, Edward K. W., Loh, Christine, Uebergang, Kylie and Xu, Stephen, The Budget and Public Finance in Hong Kong, at: http://www.civic-exchange.org/publications/2003/BudgetReport.pdf. Goodstadt, op. cit. note 44 .

Hong Kong has been characterized by a somewhat paradoxical combination of heavy public involvement in financing and provision of direct public goods (for example, housing and general, educational and health infrastructures) while at the same time maintaining comparatively low overall government spending (compared to revenues). See, Lee, Eliza, Wing-yee, The Politics of Welfare Developmentalism in Hong Kong, at: 
The rate of public welfare spending has been increasing, however. Hong Kong's ageing population and rising social welfare expectations help explain a significant part of this growth. ${ }^{115}$ It is in the area of transfer payments (direct payments by government to individual citizens) that welfare budgets in other developed countries have seen the greatest growth and where they typically exceed direct public welfare spending (on the likes of housing, schools and hospitals) significantly. Until the 1990s, Hong Kong was notable for its comparatively low level of transfer payments. ${ }^{116}$ From the mid-1990s, welfare spending of all kinds (including transfer payments) began to rise in Hong Kong. ${ }^{117}$ More recently, welfare spending has been cut back in Hong Kong as part of the efforts by the Government to curb its reliance on deficit financing of current expenditure. ${ }^{118}$ Goodstadt argues that Hong Kong's social spending policies have long been and remain deeply flawed - a position made all the more indefensible given the HKSAR's massive fiscal reserves and familiarity with world-wide best practice. ${ }^{119}$

http://www.unrisd.org/unrisd/website/document.nsf/0/B764A113DEE628D4C125706D0032DA6 6?OpenDocument.

Ibid.

In 1997, less than 5\% of public expenditure was devoted to transfer payments in Hong Kong, whilst $50 \%$ of public spending went on direct health, welfare, education and housing infrastructure. In the US, at the same time, the comparable figures were around $33 \%$ and $22 \%$, respectively. See, It is already 1997 in Hong Kong, The Economist, 18 December 1997, 27.

One commentator has estimated that broad social welfare spending increased by a total, nominal, 236\% between 1994 and 2004 (see, Dom, James A., Economic Freedom Must Lead the Way in Hong Kong, at: http://www.cato.org/dailys/11-27-04.html).

Lee, op cit. note 114 .

Goodstadt, op. cit. note 44 . 
Another factor of some importance is the HKJC. The HKJC is a not-for-profit organisation which has long held a monopoly granted by the Government to run all legal gambling activities in Hong Kong. In 2005-2006 the HKJC had a turnover of around US\$13 billion. ${ }^{120}$ The HKJC typically contributes over $10 \%$ of HKSAR Government revenues in the form of betting duties and other taxes. ${ }^{121}$ Also significant is the major public spending programme of the HKJC based on its operating surpluses. ${ }^{122}$ Hong Kong is dotted with hospitals, educational establishments and a substantial number of other public facilities all funded in full or in part by the HKJC. ${ }^{123}$

What this review demonstrates is that Hong Kong has, for decades, maintained a remarkable reliance on a distinct schedular taxation derived, originally, from the early 1800 s UK income tax system. Moreover, profits or income arising outside of Hong Kong are not subject to tax within the HKSAR. In relying so heavily on the use of both separately operating schedules and source-based taxation as fundamental principles, Hong Kong is in company, in 2005, with a small minority of other jurisdictions. Countries such as Belgium, Colombia, Croatia, and Mexico

120 See, 2005-2006 Season End Results-Hong Kong Jockey Club, at: http://www.hkjc.com/english/corporate/corp_operation_05-06_results.asp.

121 See, Lovelock, Peter and Grant, Ken, Hong Kong Chronicles, at: http://english1.e21times.com/asp/fd.asp?r=974.

122 See, Strengthening Philanthropy in the Asia Pacific: An Agenda for Action - Background Paper:Hong Kong, at: http://www.asiafoundation.org/pdf/APPC.HK.pdf. 
have now moved from a schedular system to widen the tax base in each case. ${ }^{124}$

Furthermore, unlike most other developed jurisdictions, Hong Kong imposes: no tax on capital gains; ${ }^{125}$ only very limited taxes on fringe benefits ${ }^{126}$ and; no general tax on the provision of goods and services. ${ }^{127}$ A key reason Hong Kong has been able not only to fund public spending, but to put away substantial fiscal reserves, whilst relying on such a taxation system, has been the major revenue streams from land-related transactions, where the Government deliberately positioned itself as a monopoly supplier of this vital "commodity". Moreover, in difficult years, such as those after 1997, when revenues have fallen short of spending, the Government has been readily able to cover shortfalls by accessing

Holmes, Kevin, The Concept of Income - A Multi-Disciplinary Analysis (IBFD, Amsterdam, 2001) 28-29. Holmes notes, as examples of schedule-based systems, Hong Kong, Belarus, Sudan and the UK. In the case of the UK - and unlike Hong Kong - although the schedules remain in the form, as a matter of practice, a single income tax is applied to collective income, see: Tax in England, at: http://www.adviceguide.org.uk/index/life/tax/income tax/index/life/tax/income tax.htm; and Income Tax, at: http://www.economicexpert.com/a/Income:tax.html..

Section 14 of the IRO, which imposes Profits Tax, specifically excludes capital profits from assessment of Profits Tax. Section 14 does tax "trade", however, and the case law - and the IRO definitions section (Section 2) - stipulate that this term includes "an adventure in the nature of trade". Thus, one-off transactions can still be regarded as "trading" in certain circumstances (normally fairly rapid re-selling of real estate) and taxed accordingly. See, further, Cullen, op. cit. note 86 .

Reduced taxes apply to the provision of employee housing and certain education and share benefits. Otherwise, the "cash-convertibility" rule applies. This rule, which is based on old English case law, provides that provided an employee fringe benefit is not paid in cash and cannot be converted to cash by the employee, then it will not be considered a perquisite which can be taxed as part of a salary (see, further, Cullen, ibid).

It is arguable that the Hong Kong Government's long established, high land price policy has imposed a "de facto" Consumption Tax on all consumers in Hong Kong. Inflated land prices (which have benefited the Government most of all) have driven up the costs of doing almost every sort of business in Hong Kong because of high rents or high initial land-purchase costs. These input costs have then been passed on to all consumers as prices for goods and services have been set. The introduction of a GST in Hong Kong is now a widely discussed new tax option (see discussion below and, also,: The HKSAR Government may beat its target by balancing the books before 2008/2009, PricewaterhouseCoopers predicts, at: http://www.pwchk.com/home/eng/pr_170105.html; and Ching, Stephen, GST and Government Bond, at: http://www.tdctrade.com/econforum/hkcer/hkcer040601.htm). 
accumulated reserves - a process which has not required LegCo spending approval.

In summary, Hong Kong has survived and, indeed, thrived, into the $21^{\text {st }}$ century whilst relying on a Revenue Regime which would not have been out of place in the $19^{\text {th }}$ century.

\subsubsection{The Fiscal Firewall}

A number of the main features of Hong Kong's new mini-Constitution, the Basic Law, are explained above, in Section 2.3. As we saw, one crucial role of the Basic Law is to provide for a high degree of separation of the HKSAR from the Mainland (Two Systems) within the PRC (One Country). Particular effort has been put into drafting provisions in the Basic Law which are designed to install a constitutional, "fiscal firewall" between the two Revenue Regimes.

Article 106 of the Basic Law provides that Hong Kong is to have its own independent finances and prohibits the PRC from raising taxes in Hong Kong or sharing the HKSAR's tax revenue:

The Hong Kong Special Administrative Region shall have independent finances.

The Hong Kong Special Administrative Region shall use its financial revenues exclusively for its own purposes, and they shall not be handed over to the Central People's Government.

The Central People's Government shall not levy taxes in the Hong Kong Special Administrative Region. 
Moreover, Article 108 provides that:

The Hong Kong Special Administrative Region shall practise an independent taxation system.

The Hong Kong Special Administrative Region shall, taking the low tax policy previously pursued in Hong Kong as reference, enact laws on its own concerning types of taxes, tax rates, tax reductions, allowances and exemptions, and other matters of taxation.

The Basic Law also stresses the need to preserve the prosperity and stability of Hong Kong. ${ }^{128}$

Ten years-plus after the handover, one would have to say that the policy of separating the two Revenue Regimes has been followed practically to the letter. Both economies (and the participants in those economies) operate, as a matter of routine, as if there are two entirely separate Tax Systems. This is recognized, too, in the Double Tax Arrangement in place and applying to the Tax Systems (see, further, below). Moreover, this separation is well recognized outside of the PRC and the HKSAR, for example, by the Australian Taxation Office. ${ }^{129}$

128 Preamble, Basic Law.

129 See, Australian Tax Office, Taxation Ruling TR97/19, Income Tax: Tax Implications of Resumption of Chinese Sovereignty over Hong Kong. 


\subsubsection{Double Tax Treaties}

Due to the territorial source basis of taxation, non-residents in Hong Kong are taxed at source and withholding tax, generally, does not apply. ${ }^{130}$ As only three types of income with a domestic source are taxed under a separate system of schedules, there is notably less need for Hong Kong to seek to enter into a range of DTTs to deal with the allocation of taxing rights for different types of income and to require the residence jurisdiction to provide double taxation relief for any source taxation levied in accordance with the DTT. However, Hong Kong is beginning to recognize certain trade-enhancing merits (discussed further below) of concluding DTTs with its trading partners, and has entered comprehensive DTTs with Belgium, ${ }^{131}$ Thailand ${ }^{132}$ and Luxembourg. ${ }^{133}$ For Hong Kong, the Belgium, Thailand and Luxembourg DTTs apply to any person who is resident in Hong Kong. The term 'person' includes an individual, a company, an estate, a trust or a partnership. ${ }^{134}$ Residence is not defined in the Hong Kong-Belgium

A quite limited number of payments to an offshore company are deemed to have a source in Hong Kong, and withholding tax applies even if the company does not carry on any business in Hong Kong. See, for example, Sections 15(1)(a), 15(1)(b) and 15(1)(ba) of the IRO.

See the Agreement Between the Hong Kong Special Administrative Region of the People's Republic of China and the Kingdom of Belgium for the Avoidance of Double Taxation and the Prevention of Fiscal Evasion with respect to Taxes on Income and on Capital (entered into force October 2004) (Hong Kong-Belgium DTT).

See the Agreement Between the Government of the Hong Kong Special Administrative Region of the People's Republic of China and the Government of the Kingdom of Thailand for the Avoidance of Double Taxation and the Prevention of Fiscal Evasion with respect to Taxes on Income (entered into force December 2005) (Hong Kong-Thailand DTT). China and the Grand Duchy of Luxembourg for the Avoidance of Double Taxation and the Prevention of Fiscal Evasion with respect to Taxes on Income and on Capital (signed on 2 November 2007) (Hong Kong-Luxembourg DTT). 
DTT, but any person is liable to tax "by reason of his domicile, residence, place of management or incorporation or any other criterion of a similar nature". 135 Residence is defined in both the Hong Kong-Thailand and Hong KongLuxembourg DTTs and means, in the case of companies, a company incorporated in Hong Kong or a company not incorporated in Hong Kong but being normally managed or controlled in Hong Kong. ${ }^{136}$ For the first time, the concept of residence has a limited but key role to play in Hong Kong's territorial Taxation System.

Hong Kong also has entered limited treaties relating to airline and shipping income, ${ }^{137}$ and a comprehensive Double Tax Arrangement (DTA) with Mainland China covering business profits, employment income, capital gains as well as passive income such as dividends, interest and royalties. ${ }^{138}$ The DTA is

Article 4, Hong Kong-Belgium DTT

Article 4, Hong Kong-Thailand DTT; Article 4; Hong Kong-Luxembourg DTT.

There are a number of treaties relating specifically to airline and shipping income. Hong Kong has reached bilateral air services agreements for airline income with Bangladesh, Canada, Croatia, Denmark, Estonia, Ethiopia, Finland, Germany, Iceland, Israel, Jordan, Kenya, the Republic of Korea, Kuwait, Macao Special Administrative Region, Mauritius, Mexico, the Netherlands, New Zealand, Norway, the Russian Federation, Sweden, Switzerland and the UK. Hong Kong has also entered into double taxation relief arrangements for shipping income with Denmark, Germany, the Netherlands, Norway, the UK and the US. Agreements covering both airline and shipping income have been concluded with Singapore and Sri Lanka. See, further: Doggart, Caroline, Tax Havens and Their Uses (Economist Intelligence Unit, Research Report, 2002); Olesnicky, Michael, 1997 Asia-Pacific Tax Update - Hong Kong (1997) 15 Tax Notes International, 2143; Blanco, Evan and Roels, Jan, Hong Kong Signs Its First Comprehensive Income Tax Treaty (2004) 33 Tax Notes International, 227; and Lai, David T. W., Interpreting Double Tax Agreements in Hong Kong (2007) 37 Hong Kong Law Journal, 137.

See the Arrangement Between the Mainland of China and the Hong Kong Special Administrative Region for the Avoidance of Double Taxation and the Prevention of Fiscal Evasion with respect to Taxes on Income (entered into force December 2006) (Hong Kong-China Double Tax Arrangement). See, too, Second Protocol to the Arrangement for the Avoidance of Double 
necessary to allocate taxation rights between the two sides due to increasing cross-border commercial activities and each side administering a different Taxation System. The concept of permanent establishment $(P E)$ is used in the DTA to determine where tax is to be imposed. In determining the profits of a PE, deductions are allowed for expenses incurred for the purposes of the business of the PE including executive and general administrative expenses. ${ }^{139}$ However, any royalties (paid by the PE to the head office for the right to use intellectual property), commission or remuneration for provision of specific service or management, as well as interest on moneys lent to the PE (except for banking enterprises) are not deductible.

The DTA provides a number of incentives for investing in the PRC through a holding company in Hong Kong. A Hong Kong company no longer has to pay any PRC Capital Gains Tax (CGT) when it sells shares in a PRC business, unless the Hong Kong company holds 25 per cent or more of the shareholding of the Mainland enterprise or the assets of the Mainland enterprise comprise mainly immovable property situated on the Mainland. ${ }^{140}$ The withholding tax rates on dividends, interest and royalties earned from investments in Chinese companies

Taxation signed with the Mainland, signed by the Secretary for Financial Services and the Treasury of the HKSAR on January 20, 2008. Note the terminology - this is a "Double Tax Arrangment" - not a Double Tax Agreement, still less a Double Tax Treaty. Agreements and Treaties are signed by separate, sovereign jurisdictions. The HKSAR as a part of the PRC, is not separate in this sense, hence the use of the term Arrangement. 
have been lowered to attract foreign capital and to promote Hong Kong as an international financial centre. ${ }^{141}$

\author{
As to income from employment, so far as Hong Kong is concerned, a resident of \\ the Mainland is chargeable to Hong Kong Salaries Tax on income from \\ employment in Hong Kong if the period of stay in Hong Kong exceeds 183 days \\ in the aggregate in a 12 -month period. ${ }^{142}$
}

141 Under the previous Hong Kong-China Double Tax Arrangement signed in February 1998, the withholding tax rate for dividends, interest and royalties received by a Hong Kong company was 10 per cent. Under the new Arrangement signed in August 2006, the withholding tax rate for dividends is now down to 5 per cent, if the Hong Kong company holds 25 per cent or more of the capital of the Mainland enterprise. Similarly, the withholding tax rate for interest and royalties received by a Hong Kong company is now reduced to 7 per cent. See, also, Second Protocol to the Arrangement for the Avoidance of Double Taxation signed with the Mainland, January, 30, 2008 on the definition of a "resident".

The basic charge to salaries tax is imposed by Section 8(1) of the IRO 1947 on income 'arising in or derived from Hong Kong'. In addition to this basic charge, the High Court Commissioner of Inland Revenue v George Andrew Goepfert [1987] 1 HKLR 888, decided that there is a double test under Section 8(1):

If during a year of assessment a person's income falls within the basic charge to salaries tax under Section 8(1), his entire salary is subject to salaries tax wherever his services may have been rendered, subject only to the so-called ' 60 days rule' that operates when the taxpayer can claim relief by way of exemption under Section $8(1 \mathrm{~A})(\mathrm{b})$ as read with Section $8(1 \mathrm{~B})$. Thus, once income is caught by Section $8(1)$ there is no provision for apportionment ... On the other hand, if a person, whose income does not fall within the basic charge to salaries tax under Section 8(1), derives income from employment in respect of which he rendered services in Hong Kong, only that income derived from the services he actually rendered in Hong Kong is chargeable to salaries tax. Again, this is subject to the ' 60 days rule'. Therefore, once Section 8(1) applies, there can be no claim for so-called time apportionment. If a non-Hong Kong employment exists, then any income derived from that employment is liable to salaries tax under Section 8(1A) which brings to charge income derived from services actually rendered in Hong Kong. See, also, Hong Kong, Inland Revenue DIPN 10 (revised), The Charge to Salaries Tax. See, too, Second Protocol, ibid. 
Though Hong Kong is now part of the PRC, it is excluded from, for example, the operation of the Australia-China DTT. ${ }^{143}$ The Australia-China DTT covers the Income Tax imposed under the laws of the PRC. ${ }^{144}$ The term 'China' means all the territory of the PRC, including its territorial sea, in which the laws relating to Chinese tax apply. ${ }^{145}$ Article 106 of the Basic Law provides that the PRC shall not levy taxes in Hong Kong. Article 108 stresses that the HKSAR should follow the same territorial basis and low tax rates that previously existed in Hong Kong. Accordingly, the Commissioner of Taxation in Australia does not take the view that the HKSAR taxes would be "identical or substantially similar" to the taxes imposed in China to which the DTT applies, ${ }^{146}$ and the Australia-China DTT thus does not apply to taxes imposed by the HKSAR. ${ }^{147}$

\subsection{GLOBALIZATION AND THE REVENUE REGIME}

Right from its initial, somewhat unsteady beginnings in 1841 , the Crown Colony of Hong Kong was shaped by the most powerful spur towards globalization of that era. Towards the end of the $18^{\text {th }}$ century, as Britain conceded the loss of its American Colonies, the British Empire seemed to be wobbling. Within less than

143 See the Agreement Between the Government of Australia and the Government of the People's Republic of China for the Avoidance of Double Taxation and the Prevention of Fiscal Evasion with respect to Taxes on Income (entered into force 28 December 1990) (Australia-China DTT).

Article 2, Australia-China DTT.

Article 3, Australia-China DTT.

Article 2, Australia-China DTT.

See Australian Taxation Office, Taxation Ruling TR97/19, Income Tax: Tax Implications of Resumption of Chinese Sovereignty over Hong Kong. 
50 years, however, that same Empire was entering its period of maximum reach and ascendancy. The globalized trade system of this era, pivoted around worldwide colonies gathered into predominantly European-based Empires. A fundamental tenet of British Empire ideology by this stage was the paramount need to foster international trade between London and the Empire, within the Empire and with the rest of the world. ("Manchester Capitalism" is the name given to this system by one German commentator. ${ }^{148}$ )

Very shortly after Captain Charles Elliot raised the Union Jack ${ }^{149}$ over Hong Kong Island for the first time in January 1841, he proclaimed Hong Kong to be a Free Port. As Tsang says:

[Elliot] declared that "Her Majesty's Government has sought no privilege in China exclusively for the advantage of British ships and merchants". This generous offer to open Hong Kong to traders of all nations including China was made in the light of the ascending might and rising economic power of early Victorian Britain. These were such the free trade posed little if any threat to British supremacy in Chinese waters. ${ }^{150}$

Thus, from the outset, the imperatives of globalization determined certain fundamentals of the Revenue Regime in the new colony. Deprived of income from Customs Duties (normally a mainstay of $19^{\text {th }}$ century colonial finances) the new Hong Kong Government quickly seized the opportunity, first to assert title to all land; and then to sell land-usage rights (by auction) in the form of a

148 Sieren, Frank, The China Code (PalgraveMacMillan, Basingstoke, 2007).

149 The "Union Jack" remains the most commonly used term for the Flag of the United Kingdom of Great Britain and Ireland (now Northern Ireland). See, Union Flag, at: http://en.wikipedia.org/wiki/Union_Flag. 
government monopolized commodity. ${ }^{151}$ This system was a product, in part, of the hard-learning from the loss of colonies in America (yet more global-event influence). It flourished elsewhere in the British Empire - but probably nowhere has its role as a revenue generator been so significant over such a long period as in Hong Kong (and now, still, in the HKSAR). First private parties and then the Government, also, swiftly began filling in parts of Hong Kong's (now) famous Victoria Harbour. ${ }^{152}$

A great deal of Hong Kong's trading success substantially depended for many years on the awful large scale shipment of opium to China by the British from India. It was primarily disputation with China about Britain's right to export opium that led to the First Opium War and the seizure of Hong Kong Island. ${ }^{153}$ The Hong Kong Government benefited directly from this trade through licence fees and other charges which applied. As late as 1917, it is said, up to one third of all revenue in Hong Kong arose out of opium trading activities. ${ }^{154}$

For the first 100 years in Hong Kong, the Government was able to manage not only without Customs Duties but also without need to resort to Income Tax.

151 In other places, salt and tobacco, for example, commonly were transformed into State monopolies and sold to fill State coffers. Today, many States achieve similar ends selling raw petroleum resources. Nissim, op. cit. note 60 , Chapter 6.

153 Tho'Mas, Kristianna, Opium War of 1838-42: How Britain Stole Hong Kong from China, at: http://www.hartford-hwp.com/archives/55/044.html. at: http://www.druglibrary.org/schaffer/History/om/om7.htm. 
Local business people, both Chinese and expatriate, were bitterly opposed to any sort of tax on income and especially opposed to any tax on business profits. ${ }^{155}$ Apart from this internal resistance, the fact was that, with the minimal level of government services provided, the Colony was able to survive and indeed thrive without need to increase the very limited reach of its Tax System. The assortment of taxes like Stamp Duty, Estate Duty, Property Rates and Betting Duty, coupled with various fees and, particularly, the revenue from land transaction sales and imposts - plus revenue derived from the opium trade normally generated sufficient income to cover public expenditure. The usually thriving economy was, of course, crucial to generating sufficient income from this very limited and, indeed, rather peculiar revenue base. ${ }^{156}$ The thriving economy was, in turn, primarily energized by Hong Kong's role as a crucial Free Port within the British Empire (and the world-wide trading system). In other words, the globalized economy of the time both crucially shaped the Revenue Regime - and helped sustain that same regime for decade after decade.

Then came WWII. The Japanese invaded the unstable, vulnerable new Republic of China in the early 1930s and occupied Manchuria in 1933. By 1939, the Japanese occupied Guangdong Province, adjacent to Hong Kong. Notwithstanding this clear threat and even after the UK declared war on

$155 \quad$ Littlewood, Michael, The Legacy of UK Tax Law in Hong Kong, Paper presented at the "Legacy of UK Taxation Law Abroad Conference", at The University of Hong Kong, December 18, 2007.

156 A series of punishing strikes organized from nearby Canton (today Guangzhou) in Mainland China in the 1920s (after the fall of the last Imperial (Qing) Dynasty in 1911-1912) severely tested the survival skills of the Colony, however. See Miners, Norman, The Government and Politics of Hong Kong $\left(5^{\text {th }}\right.$. Ed.) Oxford University Press, Oxford, 1998). 
Germany in 1939, resistance in Hong Kong to an Income Tax of any sort remained fierce. ${ }^{157}$ Finally, Hong Kong's first Income Tax was introduced. It applied only briefly in $1940-1941$ and then was suspended. The Japanese invaded Hong Kong on December 9, 1941, two days after they bombed Pearl Harbour. Within three weeks, they had control of the entire Colony.

Finally the Japanese were defeated, in 1945, and departed. They left a shattered economy. As devastated as that economy was, however, there was still, in the immediate aftermath of the war, a widely shared understanding that, if Hong Kong were to recover, it was most likely do so applying the same economic model which had dominated for the hundred years prior to the war. That model emphasized, above all, trade engagement with the rest of the world. That model had been shown to work best by combining a minimalist Tax System with very high levels of trade-based economic activity.

After WWII, in 1947, the IRO commenced operation. Again there was resistance to its (re)introduction, which was especially fierce from the Chinese business community. But as the war ravaged Colony was in such desperate straits, the expatriate business elite reluctantly agreed to the re-instatement of a type of limited Income Tax. ${ }^{158}$ As before the war, though, it came in a form which borrowed very heavily from the $19^{\text {th }}$ century UK Income Tax model. It was

$\overline{157 \quad \text { Littlewood, op cit. note } 155 .}$

$158 \quad$ Miners, op. cit. note 44. 
source based (its scope was confined, essentially, to the territory of the Crown Colony) tax rates were all kept notably low and no general Income Tax was allowed, rather separated specific taxes applied according to particular schedules. Once more the development of Hong Kong's Revenue Regime had been heavily constrained so as to fit, it was hoped, as well as possible into whatever new post-war, world trading (and political) order emerged.

After the defeat of Japan in 1945, the Civil War in China, between Chiang KaiShek's Kuomintang (KMT) and the CCP led by Mao Zedong resumed. By 1949, the defeated KMT had retreated to the island of Taiwan. The new People's Republic of China was proclaimed by the Communists on October 1, 1949. Hong Kong found itself, like it or not, with a front row seat at the Cold War.

Over the course of the Cold War (from 1945 to 1989) Hong Kong experienced (or was caught up in to some degree) various regional crises including: the Korean War, the upheaval and famine of Mao's infamous "Great Leap Forward" (19581961) ${ }^{159}$; Mao's even more ill-famed, "Great Proletarian Cultural Revolution" $(1966-1976)^{160}$; and the Vietnamese War. Perhaps the most severe proxysubstantial-wars driven by the Cold War political order were those in Korea and Vietnam.

159 Great Leap Forward, Cambridge Paperback Encyclopedia (3 ${ }^{\text {rd }}$ ed.) (Cambridge University Press, Cambridge, 1999). 
Although the People's Liberation Army (of the CCP) was on the border with Hong Kong by 1949 , no attempt was made to invade. By 1950, China had entered the war on the Korean Peninsula on the side of North Korea. This made any nearterm invasion of Hong Kong unlikely for several reasons. First, the limited resources of the new PRC were already stretched by the war in the north-east. Also, the British were, by now, well dug in, in Hong Kong. Next, the Korean War demonstrated, to Beijing, the advantage of having this British enclave in the south-west. Following the outbreak of the Korean War, the Western powers placed an embargo on the export of strategic goods to the PRC. China, was, nonetheless, able to obtain some important supplies through Hong Kong. ${ }^{161}$

Out of this experience grew a largely unspoken, mutual understanding between Beijing and London. The essence of this understanding was that, provided Hong Kong did not become any sort of strategic threat to the PRC, the British presence there would be tolerated pro tempore. The key elements of this modus vivendi, according to Norman Miners, included: no significant moves towards democracy in Hong Kong; no effective Taiwanese (that is, KMT) presence in Hong Kong; and no impediments to China participating in and profiting from the Hong Kong economy. ${ }^{162}$

$161 \quad$ Miners, op. cit. note 44.

162 Ibid. 
Under this arrangement, Hong Kong enjoyed a near continuous, significant growth in prosperity for a period of five decades following the end of WW II. In 1945, Hong Kong's per capita Gross Domestic Product (GDP) was, by some estimates, lower than that of India and Kenya. ${ }^{163}$ By 1992, Hong Kong's per capita GDP had overtaken that of the UK. By 2004, Hong Kong was ranked at 23 in a global, "highest GDP per head" table, ahead of Canada and Australia. ${ }^{164}$ Wealth distribution in Hong Kong remains very uneven; significant poverty persists. But there is no denying that the City-State materially transformed itself over the decades following 1945, from a war ravaged colony of less than $800,000^{165}$ to a leading international service centre with a population of some 7 million.

Crucial to this transformation was Hong Kong's rapid, highly adaptive reintegration into the new, post-Empire (Cold War influenced) world trading system. Initially, manufacturing for export was very successfully added to the traditional trading foundations of the economy. At least two factors combined to drive this development. First, much manufacturing talent fled Mainland China for Hong Kong following the creation of the PRC in 1949. Next, the American-led trade embargo imposed on the PRC following the outbreak of the Korean War in 1950 notably restricted Hong Kong - Mainland trade (though it did not stop it

163 Bartholomew, James, The Welfare State Made Britain Poor - extract from book at: http://www.moneyweek.com/article/593//the-welfare-state-made-britain-poor.html.

164 Pocket World in Figures 2005 (The Economist - Profile Books, London, 2004), 28.

165 See, http://www.demographia.com/db-hkhist.htm. 
altogether). This restriction on traditional China-entrepot-trade forced Hong Kong to seek fresh (manufacturing-based) trading opportunities. ${ }^{166}$ Later came tourism and a Vietnam War, rest and recreation role. Increasingly, service industries (banking, legal accounting and the like) grew to be important and Hong Kong became a preferred location of regional headquarters for many transnational corporations. $^{167}$ By this stage, Hong Kong's basic financial and legal infrastructure (including a genuinely strong Rule of Law ethos) were both well established and well recognized. ${ }^{168}$

In 1972, US President Nixon visited the PRC following the lifting, in 1971, of the US embargo on trade in non-strategic goods. This signaled that Hong Kong's historical role as an entrepot to China could once more resume. ${ }^{169}$ Commencing in 1978, China's new post-Mao, Premier Leader, Deng Xiaoping, launched China's whole-hearted economic reconnection with world with the "open-door" policy. ${ }^{170}$ Very quickly, Hong Kong entrepreneurs moved to take advantages of these changes - taking real risks as they did so - by shifting all manner of manufacturing facilities across the border into Guangdong Province and especially into the border, Special Economic Zone of Shenzhen. As this process

\footnotetext{
166 Tsang, op. cit. note 59, Chapter 12.

167 Ibid.

$168 \quad$ Ibid.

169 Ibid.

170 Sieren, Frank, The China Code (Palgrave MacMillan, Basingstoke, 2007) Chapter 6.
} 
gathered momentum, Hong Kong's role as a financial and trade logistics centre grew still further. ${ }^{171}$

Once more the fiscal chemistry worked splendidly. Hong Kong's low, simple Tax System (very significantly under-pinned by the extraordinary continuing reliance on land-transaction-related revenues) was esteemed by traders, manufacturers, the service sector and workers alike. Trade boomed. The Revenue Regime both benefited from this and, due to those low simple taxes, helped amplify Hong Kong's economic success. At base, what it did was leave most income, whether in the form of profits, rent or wages, in the hands of Hong Kong persons. Re-investment proceeded apace. ${ }^{172}$ Despite being so taxpayerfriendly, the system still, year after year, generated more revenue than the Government spent, so surpluses accumulated. Moreover, the Government was able to retain healthy surpluses while spending increasingly major amounts on public housing and health, education and general infrastructure provision. ${ }^{173}$ The glowing economic success arising out of Hong Kong's globalized connections cemented support for the minimalist Tax System. And this despite the fact that it was (and still is) widely acknowledged that Hong Kong's Tax System is outdated. ${ }^{174}$ Indeed, the IRO, the centre-piece of the current regime,

\footnotetext{
$171 \quad$ Tsang, op. cit. note 59, Chapter 12.

172 Ibid.

173 Ibid. The Government spent comparatively little in the form of transfer payments to individual persons, however (see footnote 116).

174 The Hong Kong Government acknowledges that this is so. See: Public Finance - Need to Broaden Tax Base, at: http://www.info.gov.hk/yearbook/2003/english/chapter03/03_04.html. See,
} 
has remained essentially unchanged in its fundamentals from the time it was introduced in 1947, despite the fact that, since then, three major re-examinations of the IRO by Review Committees have taken place (in 1954, 1968 and 1976).

Since 1997, for a variety of reasons the Revenue Regime has been fairly severely tested both directly and indirectly. These reasons include: the learningcurve problems of the first HKSAR Government; the impact of the AFC; other regional challenges (including the SARS crisis) and adapting to the new politicaleconomic relationship with Beijing.

The new Government found itself plunged into repetitive, substantial budget deficits from the late 1990s until around 2005. The primary causes of this included across-the-board sinking asset prices (a product of the AFC and the HKD peg to the $U S D^{175}$ ), stalled growth, and entrenched consumer-price deflation, leading to a period of year-on-year recession not seen in Hong Kong since WW II. This experience made the narrowness of the overall tax base in Hong Kong clearer than ever before. ${ }^{176}$

too: the proposals put forward by the British Chamber of Commerce in Hong Kong at http://www.britcham.com/asp/ArticleDetail.asp?ArticleId=259; Brown, Stephen, Fung, Edward K. W., Loh, Christine, Uebergang, Kylie and Xu, Stephen, The Budget and Public Finance in Hong Kong, at: http://www.civic-exchange.org/publications/2003/BudgetReport.pdf; and, Editorial, Tsang should make a stand on GST, South China Morning Post, November 17, 2005, A16. See footnotes 40 and 102 . 11. 
In response, the Government eventually set up, in 2000 , an Advisory Committee on New Broad-Based Taxes. In its report, ${ }^{177}$ the Committee agreed that Hong Kong's tax base was very narrow by international standards and that this characteristic, in addition to leading to low revenue productivity during economic downturns, exacerbated economic distortions and was slow to adjust to changing demographics.

By 2004, the HKSAR Government had concluded that reform of the Tax System was required. ${ }^{178}$ It remains unsure about the nature and extent of that reform, however. Fundamental issues that need to be addressed are numerous, and include how the Government can best be weaned from its continuing, excessive dependency on revenues derived from land-related transactions, whether reforms should be considered to widen the tax base, and how the tax burden can be shared more fairly under any reformed system. In addition to the above, there are other important concerns that arguably suggest the future use of "green taxes" in Hong Kong. ${ }^{179}$

177 See: http://www.fstb.gov.hk/tb/acnbt/english/finalrpt/finalrpt.html.

178 See: Public Finance - Need to Broaden Tax Base, at: http://www.info.gov.hk/yearbook/2003/english/chapter03/03 04.html.

179 VanderWolk, Jefferson, Broadening Hong Kong's Tax Base: Politically Acceptable Broad-based Consumption Taxes, A submission in response to the Hong Kong's Government's Consultation Document on Tax Reform, dated July, 2006 and the Interim Report thereon dated December, 2006 (on file with authors). 
In July 2006, the Government produced a public discussion document, "Broadening the Tax Base" ${ }^{180}$ Not surprisingly, given the document's title, the Government made clear therein that its main objective in seeking to reform the tax system was to widen the tax base, as opposed to increasing tax revenue. Thus, increases in the rates of existing income taxes were not seen as appropriate. According to the document, not only would such increases fail to expand the tax base, they would also be contrary to the international trend towards lowering income tax rates, and thus risk losing mobile labour and capital to other jurisdictions. ${ }^{181}$

In the document, the Government considered several alternative ways of broadening the tax base: the introduction of new taxes (a Capital Gains Tax, a Goods and Services Tax (GST), a tax on dividends); an increase in the proportion of citizens paying Income Tax (through a reduction in personal allowances); and the taxation of the world-wide income of citizens. Of these alternatives, the Government came out strongly in favour of the GST option. The Government gave several reasons for this choice. First, currently Hong Kong's tax base has, by international standards, a low reliance on taxes from goods and

See: http://www.taxreform.gov.hk/eng/doc and leaflet.htm. In the Hong Kong context, the term "tax base" is used as shorthand when discussing the specific local problem of: (A) having a narrow mix of possible taxes; which (B) often only apply (for a range of reasons) to limited segment of taxpayers otherwise prima facie liable to pay the relevant tax. More general definitions are as follows: Definition 1 - Measure upon which the assessment or determination of tax liability is based. For example, taxable income is the tax base for income tax and assessed value is the tax base for property taxes; Definition 2 - Total of taxable assets, income, and assessed value of property within the tax jurisdiction of a government. See: Business Dictionary Definition of Tax Base, at: $\underline{\text { http://www.businessdictionary.com/definition/tax-base.html. }}$. 
services. Second, as the population ages, the Salaries Tax base, on which government revenues now rely significantly, will fall in relative terms. Third, the GST was seen as providing a comparatively stable revenue base. Fourth, being broad-based, it would not need to be introduced at a high rate. Fifth, it is seen to be fair, in the sense that individual consumption determines the tax burden. Sixth, it is difficult to avoid. Seventh, it is capable of growing in line with the economy, in spite of an ageing population. Finally, by obviating the need for increases in other taxes, it would maintain Hong Kong's competitiveness. ${ }^{182}$

At the same time as releasing the document, the Government instigated a public consultation period (from July 2006 to March 2007) on the possible directions for reform. However, after the announcement of the public consultation period, Hong Kong quickly witnessed a series of significant demonstrations against the proposed GST. Given the intensity of opposition to the GST in the streets (echoed in much of the media) and the fact that political parties from across the political spectrum (pro-Government/Beijing and pan-democrat) expressed hostility to the tax, the Government withdrew it as an option "on the table" in December 2006, well before the consultation period was over. ${ }^{183}$ Since the incumbent Chief Executive (Political Leader) of the HKSAR, Donald Tsang, was

182 Ibid.

183 Cheng, Jonathan, Sales tax fiasco clouds Tang's fourth budget, The Standard, February 26, 2007 at:

http://www.thestandard.hk/news detail.asp?we cat=4\&art id=38915\&sid=12372543\&con type= 3\&d str=20070226. Hong Kong's political parties remain divided primarily according to whether they support faster-paced or slower/very slow-paced further democratization, with pro-Beijing and pro-Government parties all being in the latter camp. 
facing a form of election in March 2007, it might have been that his campaign advisers also thought it wise to "bury" the GST proposal so it could not become an issue during the main election campaign. ${ }^{184}$

Tax reform is one of several issues where the Government swings between policy boldness and policy timidity. With current tax revenue streams now back at very high levels, the Government can, today, more readily postpone boldness until another day. ${ }^{185}$ The structural weaknesses identified in the Hong Kong tax system during the recent debate remain in place, however. In particular, the tax base remains as narrow as ever - and the distorting impact of the Government's Donald Tsang was re-elected as CE in March 2007. His sole opponent was Alan Leong (a leading barrister and prominent member of the pro-democracy Civic Party). This was, however, an election which Mr Tsang could not lose. Ultimate control by Beijing of the composition of the clear majority of the 800 member Election Committee (see: Annex 1 of the Basic Law) ensured this. Still, for the first time since the creation of the HKSAR, Hong Kong witnessed a genuine campaign contest - with competing, comparatively detailed policy debates (including two live television debates). For a sharp commentary on this recent election, see: Kwok, Kar Ki, Letter to Hong Kong, Radio Television Hong Kong, February 11, 2007 at:

http://gbcode.rthk.org.hk/b5i/www.rthk.org.hk/rthk/radio3/lettertohongkong/20070211.html. For a good discussion of the importance of fiscal issues related to that campaign see: Tsang, Yok Sing, Can Fiscal Prudence Survive Democracy?, at:

http://www.dab.org.hk/en/main.jsp?content=article-content.jsp\&categoryId=1241\&articleId=482. original push for a GST - there were calls for reductions in existing taxes. See: Eng, Dennis, Windfall in revenue spurs tax relief call, South China Morning Post, July 16, 2007, A1. These calls have now been agreed to by the Chief Executive. See: Cheung, Jimmy, Tsang sets "new direction" for HK, South China Morning Post, October 11, 2007, A1. 
addiction to land-transaction revenues remains deep-rooted. ${ }^{186}$ Tax reform has been delayed but not postponed indefinitely. ${ }^{187}$

Richard Cullen and Richard Simmons of Lingnan Unversity in Hong Kong completed, in May, 2007 the first face to face survey (of almost 800 residents) in Hong Kong looking at a broad range of attitudes towards the operation of the current Tax System (and also the political arrangements) in the HKSAR. ${ }^{188}$ On wide tax reform issues, the survey highlights mostly positive - or, at least, nonhostile - views on a range of matters, including, acceptability of the current Tax System, tax fairness, and the cost-effectiveness of government taxation and expenditure. The study also confirms that Hong Kong citizens remain notably apprehensive about the introduction of new taxes. However, Hong Kong people are increasingly concerned about the deteriorating environment, and they may be receptive to the Government implementing certain new "green taxes" if these can be shown to help redress environmental degradation whilst also raising revenue. ${ }^{189}$

186 In just one quarter of the financial year, April 1, 2007- March 31, 2008, Government direct land transaction revenues totalled over \$US1.1 billion (see: Government makes \$8.7 billion from land sales, Radio Television Hong Kong News, July 17, 2007, at:

http://www.rthk.org.hk/rthk/news/englishnews/news.htm?englishnews\&20070717\&56\&416399.

The CE of the HKSAR, Donald Tsang, noted in his 2007 Policy Address on October 10, 2007 that Hong Kong's narrow tax base remained a major concern. See: Cheung, Jimmy, Tsang sets "new direction" for HK, South China Morning Post, October 11, 2007, A1. 
Some further interesting collective views are highlighted by the study. For example, it seems clear from the survey data that, despite exhibiting large (and increasing) wealth disparities, the HKSAR does not present fertile ground for creating a democracy-driven, advanced welfare state. ${ }^{190}$ The survey data also indicate that the demand for greater democratization in Hong Kong is high. Some linkages between tax reform and political reform appear to exist, but the The advanced welfare state can be characterized as: "[O]ne of the hallmarks of the "Golden Age" of post-war prosperity, [which] implied more than a mere upgrading of existing social policies in the developed industrial world. In the broadest of terms, it represented an effort to bring about economic, moral and political reconstruction. Economically, it departed from the orthodoxies of the pure market nexus and required the extension of income and employment security as a right of citizenship. Morally, it sought to defend the ideas of social justice, solidarity and universalism. Politically, the welfare state formed part of a project of nation building, affirming liberal democracy against the twin perils of fascism and bolshevism. Many countries became selfproclaimed welfare states, not so much to give a label to their social policies as to foster national social integration." Esping-Andersen, Gosta, After the Golden Age: The Future of the Welfare State in the New Global Order (United Nations Research Institute for Social Development - Paper Number 7) at:

http://www.unrisd.org/80256B3C005BCCF9/(httpPublications)/D93F019CFA85A04280256B650 041F3F5?OpenDocument. Hong Kong has what has been described as a "residual welfare state" where public transfers to individuals are notably limited but where public spending on the provision of infrastructure is significant. See: Lee, Eliza, Wing-yee, The Politics of Welfare Developmentalism in Hong Kong, at: http://www.unrisd.org/unrisd/website/document.nsf/0/B764A113DEE628D4C125706D0032DA6 6? OpenDocument. On poverty in the HKSAR, see, Gordon, Peter, Distribution of wealth so poor, The Standard, October 3, 1997, at:

http://www.thestandard.com.hk/news_detail.asp?pp_cat $=15 \&$ art $i d=54360 \&$ sid $=15557321 \&$ con type $=3$. See also: Poverty in Hong Kong, Hong Kong Council of Social Services, at: http://www.hkcss.org.hk/pra/ecp/pov_rate 91-05.pdf . (This study also showed that the Ginicoefficient figure in the HKSAR in $2001(0,525)$ was even higher than that applying in the Mainland PRC (0.447) in the same year.) See, too: Oxfam Advocates Legislation of Minimum Wage, Oxfam, Hong Kong, at: http://www.oxfam.org.hk/english/; Zou, Hanru, Opportunity Trumps Wealth in Hong Kong, China Daily, at: http://www.chinadaily.com.cn/opinion/200707/20/content 5439984.htm; and Fact Sheet. Gini Coefficient, Legislative Council, Hong Kong, Research and Library Division, at: http://www.legco.gov.hk/yr0405/english/sec/library/0405fs07e.pdf. The HKSAR Government contends that raw Ginicoefficient figures can be misleading and that the real situation in Hong Kong is not as bad as that indicated by such figures. Moreover, it argues that, in an economy in transition to one largely knowledge- and skills-based,, such figures are likely to be amplified (during the transition period). See: Chan, K. C., Gini-coefficient, Response to LegCo Question, by Prof. K. C. Chan, Secretary for Financial Services and the Treasury, July 4, 2007, at: http://www.info.gov.hk/gia/general/200707/04/P200707040186.htm. 
two zones of reform are seen, overall, as primarily giving rise to stand alone issues. ${ }^{191}$

Hong Kong's minimalist Tax System, notably shaped for well over 150 years by (changing) globalization forces, thus seems still to be well regarded across the socio-economic spectrum in the HKSAR.

There is one area of the Tax System where some significant change has been taking place, however, and that is the increasing tendency for the HKSAR to seek out and sign general double tax instruments. The general DTTs (with Belgium, Thailand and Luxembourg) and the broad DTA (with Mainland China) are discussed above. Here, we should note that, once more, there is good evidence that trading / globalization factors are what have driven this current move to remodel the HKSAR Revenue Regime, to a degree.

First, Hong Kong's relationship with the Mainland is now such that the already strong economic integration is accelerating. This, in turn, mandates the need for much greater clarity with respect to the impact of the two separate Tax Systems on a very wide range of cross-border activities, hence the need for the DTA. Next, the negative impact of Hong Kong's lack of an extensive DTT network with its many trading partners is, today, becoming more of a concern.

191 Cullen and Simmons, op. cit. note 188. 
Macdonald and Pandiri put it this way:

The absence of treaty protection can lead to foreign income paid to Hong Kong being subject to higher rates of withholding tax by the country from which the foreign income is paid.

In addition, Hong Kong's liberal, low taxation system may result in a Hong Kong's subsidiary being subject to the controlled foreign corporation or other anti-tax deferral laws of many countries in which the shareholders are based, for example, Australia, Canada, Japan, the United Kingdom and the United States.

Interest expense deductions are severely limited in Hong Kong. For example, interest expense is only deductible if one of these conditions is met:

- the interest expense relates to funds which are borrowed by a financial institution;

- the lender, not being a financial institution, is subject to tax in Hong Kong on the interest received;

- the principal was borrowed from a financial institution and was not secured or guaranteed by any deposit of which the interest is not chargeable to Hong Kong tax;

- the principal is borrowed from an unrelated party and is used to purchase plant and machinery or trading stock; or

- the principal is borrowed by the issue of a corporate debenture or other such public issue.

In other words, it is very difficult for interest expense to be deductible when it is paid to an affiliated company outside Hong Kong. Furthermore, interest related to funds used to acquire shares would not be deductible unless the shares are held as part of the borrower's trading stock/inventory. ${ }^{192}$

One feature of the three general DTTs signed so far is worth noting. Although each of these DTTs allow for exchange of certain information already held, none of them allows one jurisdiction to request that the other jurisdiction proactively

192 Macdonald, Barry and Pandiri, Sujata ,Hong Kong: Post-1997 Corporation Tax Issues (1997) 3 Asia-Pacific Tax Bulletin, 27. 
seek information on particular matters in the manner set out in Article 4 of the

OECD Model Tax Convention (2005), which provides, inter alia, that:

If information is requested by a Contracting State in accordance with this Article, the other Contracting State shall use its information gathering measures to obtain the requested information, even though that other State may not need such information for its own tax purposes. ${ }^{193}$

How successful the HKSAR will be in signing further DTTs whilst retaining the limited disclosure requirements found in the 1998 version of the OECD Model Tax Convention remains to be seen. ${ }^{194}$ That said, the instruments signed with Belgium and Luxembourg provide useful DTT platforms for enterprises operating between the HKSAR and potentially other countries in the European Union (EU) and perhaps beyond - rather than just Belgium and Luxembourg. ${ }^{195}$

\subsection{CONCLUSION}

Consider the Imperial British perspective in the mid-to-late $18^{\text {th }}$ century; it was their Empire, so surely they could tax it as they wished?. Most controversially, this attitude led to taxing the American Colonies, from London, of that British Empire. The long-distance taxes which London attempted to impose on the American Colonies included Stamp Duties and other indirect taxes. Favourable

193 Organization for Economic Cooperation and Development (OECD) Model Tax Convention (15 July 2005 version). See, also, Blanco, Evan and Roels, Jan, Hong Kong Signs Its First Comprehensive Income Tax Treaty (2004) 33 Tax Notes International, 227. actual taxes specifically covered in the particular DTT - see, de Ridder, Pieter and Van Gompel, Jan , Hong Kong's International Gateway: Belgium (2005) 11 Asia-Pacific Tax Bulletin 120. 
(to the East India Company) arrangements which related to the selling of tea, were also imposed on the American Colonies. These measures proved to be no less inflammatory to colonial political sentiment in America. ${ }^{196}$ War followed. The consequent defeat of Britain, by $1781,{ }^{197}$ was confirmed by the Treaty of Paris (which formally ended the war) in $1783 .^{198}$

By 1841, the British were well recovered from Imperial humiliation in America. But lessons had been learned which were to have an important impact of the preferred form of Revenue Regime to be used in new British Colonies. Most notable was the shunning of direct, London-imposed taxation and an emphasis "In 1765, the British government imposed a stamp duty on all official documents in the colonies. The idea was to help pay for the rising defence costs of the colonies - the majority of which was still being borne by the British government. The 13 disparate colonies suddenly found a common voice in their antipathy towards this taxation. The furore was abated when the government withdrew the Stamp Acts but was further ignited in 1768 when new indirect taxes were introduced. These also were hastily withdrawn when the depth of feeling was demonstrated to the government. Revolutionary feelings may well have subsided but for the fact that the East India Company had been experiencing financial problems. To help ease their financial burdens, the government agreed to break their own Navigation Acts and allow the company to sell their tea direct to America. This should have made tea attractively inexpensive in the thirteen colonies; despite the fact that the colonists would have to pay a small duty there. Unfortunately, the British misread the mood of the colonists who were not prepared to have the principle of taxation imposed on them in any form whatsoever. The so-called 'Boston Tea Party' ensued as angry opponents of the tax boarded three ships on Boston harbour and threw their chests of tea into the water. Britain's response deeply concerned all of the other colonies; heavy fines were imposed and the port was to remain closed until the tea had been paid for. Many colonists deduced that their rights could not be safe guarded against the whims of a British government and they prepared themselves for war as they declared themselves independent in 1776... A A combination of American soldiers surrounding Lord Cornwallis at Yorktown and a large French fleet blockading the coast led to their final humiliating surrender in 1781. The First British Empire came to an end, but British interests would still remain in the continent as Canada received a huge influx of loyalists fleeing Revolutionary America which would allow it to consolidate and expand its own borders." See, http://www.britishempire.co.uk/maproom/13colonies.htm.

197

Ibid.

See, The Paris Peace Treaty of 1783, at: http://www.earlyamerica.com/earlyamerica/milestones/paris/. 
on creating stand-alone, locally-anchored Revenue Regimes. A mainstay of this revised approach was, if at all possible, to place land sales, land transaction charges and land taxes at or close to the pivot of each new colonial financing strategy.

When the British established the foothold adjacent to China they had long coveted, on Hong Kong Island, the attractions of a land-focussed Revenue Regime were amplified by the decision, from the outset, to make Hong Kong a Free Port. This choice denied Hong Kong access to Customs Duties, another traditional bastion of colonial finances. For the first 100 years of British Hong Kong, the Revenue Regime installed during the foundation years of the Colony, remained largely unchanged. In addition to income from land sales, property rates and land-transaction imposts, the Colony relied on a limited range of other sources, including certain fees and charges, Excise Duties and Stamp Duties. When one considers that in the hundred years between 1841 and 1940, the population grew 100 -fold, from under 8,000 to over $800,000,{ }^{199}$ to have maintained such a stable Revenue Regime is quite a feat.

How was this managed?

- First, the total area comprising the Crown Colony increased greatly, initially in 1860 and then in 1898. This expansion explains part of the population increase. A key explanatory factor of the durability of the early Revenue Regime was the land-as-commodity funding which was a central feature of the system. The expansion of Hong Kong increased the public "land-bank" greatly. 
- Another key factor was the comparatively low cost of providing government services. Services were limited in keeping with $19^{\text {th }}$ century practice but even more so given the remarkable self-reliance (repeated examples of dire poverty notwithstanding) of the majority Chinese population. Defence costs were borne, primarily, by London. Hong Kong was an outpost far from London - and other substantial parts of the British Empire. Defence costs were significant.

- A third factor was the remarkable economic success of the new Free Port. A great deal of that success pivoted for many decades around the industrial scale shipment of opium to China by the British from India. (It was primarily disputation with China about Britain's right to export opium that led to the First Opium War and the seizure of Hong Kong Island.) The Hong Kong Government benefited directly from this trade through licence fees and other charges which applied. As late as 1917, the Colonial Office noted that up to one third of all revenue in Hong Kong arose out of opium trading activities. ${ }^{200}$

- On these foundations, however, was built an extraordinarily successful trading economy which was not opium-reliant. ${ }^{201}$ The very high levels of economic activity have been an important factor in maintaining sufficient revenues using a minimalist taxing approach. That minimalist taxing approach has, in turn, amplified the attractiveness of Hong Kong as a trading centre.

One truly major change to the Hong Kong Revenue Regime was the introduction of Income Tax just on 100 years after the founding of British Hong Kong. In the teeth of immense local resistance from the business community, the Government first introduced Income Tax in 1940 and then the IRO in 1947. The threat of war generally - and Japanese invasion particularly - drove the first initiative. The need to find a new revenue source to fund reconstruction of the war-ravaged La Motte, Ellen N., The Opium Monopoly (MacMillan, New York) 1920) Chapter 7 (Hong Kong) at: http://www.druglibrary.org/schaffer/History/om/om7.htm. China, the officially sanctioned trade in opium between Hong Kong and Mainland China was increasingly and notably reduced between 1907 and 1917. See, La Motte, ibid., Chapter XV, The History of the Opium Trade in China. 
Colony drove the second. Still, the Income Tax adopted in both cases was designed to retain low rates and to be quite limited in its application through the use of source-based, schedular taxation.

It is worth noting that the post-war Governments of Hong Kong were, in fact quietly but actively hostile to the idea of seeking low-cost development finance from the World Bank when Hong Kong was being re-built right through into the 1960s. Almost certainly Hong Kong would have qualified to borrow from this then new international financial institution (which had been established in 1947). Successive Hong Kong Governments implied they would accept such loans if they were offered on "reasonable terms" - whilst, in reality, avoiding entering into any such borrowing for fear of the way the World Bank might begin to demand changes in the Hong Kong Government's preferred economic model. In particular, the Government worried that the World Bank would strongly advocate the adoption of a more modern Tax System and insist on the collection of proper economic statistics. ${ }^{202}$

Hong Kong is now - and has been for some decades - a First World City-State. But the Revenue Regime it has today looks not that much different to that applying more than 60 years ago. It is genuinely difficult to think of many other developed jurisdictions (apart from "mono-culture" gambling economies,

202 Goodstadt, Leo, Profits Politics and Panics: Hong Kong's Banks and the making of a Miracle Economy, 1935 - 1985 (Hong Unversity Press, Hong Kong, 2007) 98-100. Hong Kong, thus, opted to reject certain globalizing influences - when they threatened to interfere, at all, with localized economic decision making. 
perhaps) where this is so. Moreover, once one removes Income Tax from the frame, the structure of today's Revenue Regime in Hong Kong retains a look that is not all that different from the basic structure applying 100 years ago. The HKSAR's new found interest in DTTs may modify the overall look of the Revenue Regime to a degree over the coming decades. But the impact of such changes looks like being fairly marginal. A more drastic change that does look possible within a decade or two is the introduction of a general consumption tax or GST.

As we consider the interaction between the phenomenon of globalization and the shaping of municipal Taxation Systems, Hong Kong presents itself a most interesting jurisdiction. The discussion above demonstrates, however, that Hong Kong is a rather special case. Distinctive factors related to Hong Kong itself explaining why this is so include: (A) the special viability (due to Hong Kong's confined size) of the land-as-commodity revenue scheme; (B) the crossgenerational, consistent, energy, hard work, intelligence and remarkable selfreliance of the local population; ${ }^{203}$ (C) the income generating (and capital wealth building) role of decades of involvement in the opium trade; (D) basically sound, long-term institutional development; $(E)$ the geographic location generally and proximity to China in particular; $(F)$ the free-port based engagement with international trade from day one of British Hong Kong; and (G) Victoria Harbour.

203 There is claim, possibly apocryphal, that Friedrich Hayek once observed that socialism is an excellent system - for up to 12 people. The socio-economic operation of the typical Chinese family lends a certain positive credence to this claim. 
Hong Kong, it turns out, also made the most of its "First Mover Advantage". Later trumpet players may emulate and even show notably greater technical skill than Louis Armstrong. But no matter how good they may be, only Louis Armstrong can be Louis Armstrong.

All of this suggests that any specific detailed lessons Hong Kong may offer in terms of comprehensive Tax Policy development are limited.

Some broad lessons are suggested by the Hong Kong experience, however. First, long-term active and consistent engagement with a globalized world can be used to help drive remarkable local advantage. Next, this kind of engagement can assist in shaping and sustaining a durable, comparatively simple Revenue Regime. Finally, the low tax-related transaction costs in Hong Kong come at equity and revenue-leakage costs, but, in the final squaring of the ledger the question is at least raised whether this approach may, in the long-run, promote greater cost-effectiveness (and lower, overall citizen tax-hostility) than more modern, more perfected, more complex Tax Systems.

Due to its striking, comparative simplicity, the Hong Kong Tax System may better satisfy the test most commonly associated with William of Occam (1285 - 1349 AD) than most other developed-world, tax jurisdictions. This test, often referred 
to as "Occam's Razor", states: "Pluralitas non est ponenda sine neccesitate" or "plurality should not be posited without necessity". ${ }^{204}$

204 See, further, Occam's Razor, at: http://www.skepdic.com/occam.html. Australia recently announced yet another extensive review of its complex Tax and Transfer Payment Systems. The Federal Government panel set up in 2008 to review Australia's Future Tax System has now issued the primary Discussion Paper (DP) for this new review. It is entitled, The Architecture of Australia's Tax and Transfer System (http://www.taxreview.treasury.gov.au/Content/downloads/report/Architecture_of_Australias tax and transfer_system.pdf). The DP comprises 340 pages of dense detail on the operation of the Australian Tax System and Transfer Payments System and the way they interact (or fail, properly, to interact). "The review has found 125 taxes in Australia across all jurisdictions - apparently simply enumerating them was difficult given the state of data available - but $90 \%$ of revenue is earned from just 10 of them. The remaining 115 taxes - and many of them are Commonwealth, not State taxes - yield only $10 \%$ of revenue." (Keane, Bernard, Dense Detail on the Root and Branch of Tax, Crikey E-Newsletter, August 6, 2008). Australia's Tax System has, over time, arguably achieved significant plurality beyond necessity. 